\title{
Shifting Shoals and Shattered Rocks How Man Has Transformed the Floor of West-Central San Francisco Bay
}

With 3-D Map Supplement

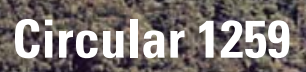

Orotar 259

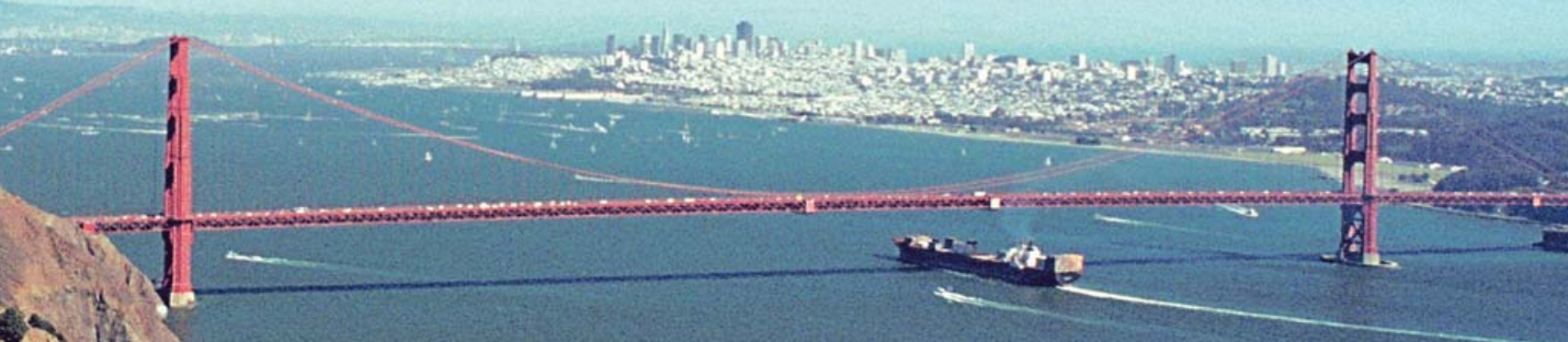

5.t. $x^{2}+1$

$-x^{2}$
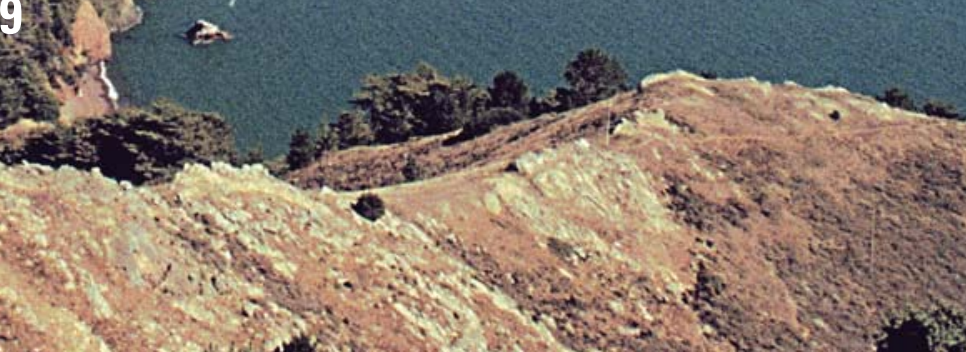

W.

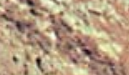

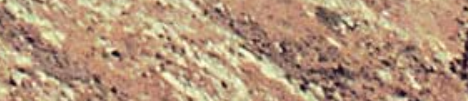
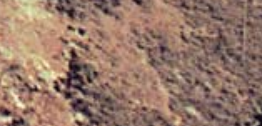

$t>t>t$

1879-2004

125 years of science for America

U.S. Department of the Interior

U.S. Geological Survey 
Cover-San Francisco Bay is one of the world's finest natural harbors and a major center for maritime trade. Since the 1850's, the margins and floor of the bay have been greatly modified by human activity. Several submerged bedrock knobs in the central bay protrude through the sediment of the bay floor and rise to within about 40 feet $(12 \mathrm{~m}$ ) of the water surface. These rocks have been lowered by blasting several times in the past, but they remain a potential hazard to shipping because cargo vessels transiting the bay increasingly have deeper drafts. This panoramic view from the Marin Headlands shows a large container vessel passing beneath the Golden Gate Bridge and entering west-central San Francisco Bay. The San Francisco-0akland Bay Bridge, in the distance to the left of the San Francisco skyline, connects to Yerba Buena Island, Alcatraz Island (back cover) is just to the left of the northern pylon of the Golden Gate Bridge, and the low-relief feature just above Alcatraz is Treasure Island. (USGS Photograph by Michael F. Diggles.) 


\section{Shifting Shoals and Shattered Rocks-How Man Has Transformed the Floor of West-Central San Francisco Bay}

By John L. Chin, Florence L. Wong, and Paul R. Carlson

With 3-D Map Supplement

Under San Francisco Bay-

A New View of the Floor of West-Central San Francisco Bay

By David A. Cacchione, Paul R. Carlson, Pat F. Chavez, Jr., John L. Chin,

Peter Dartnell, James V. Gardner, Helen Gibbons, David M. Rubin,

Miguel Velasco, and Florence L. Wong

Circular 1259

U.S. Department of the Interior

U.S. Geological Survey 


\section{U.S. Department of the Interior \\ Gale A. Norton, Secretary}

\section{U.S. Geological Survey \\ Charles G. Groat, Director}

U.S. Geological Survey, Reston, Virginia: 2004

Available from U.S. Geological Survey Information Services

Box 25286, Denver Federal Center

Denver, CO 80225

This report and any updates to it are available at http://geopubs.wr.usgs.gov/circular/c1259/

Additional USGS publications can be found at http://geology.usgs.gov/products.html/

For more information about the USGS and its products;

Telephone: 1-888-ASK-USGS (1-888-275-8747)

World Wide Web: http://www.usgs.gov/

Any use of trade, product, or firm names in this publication is for descriptive purposes only and does not imply endorsement of the U.S. Government.

Although this report is in the public domain, it contains copyrighted materials that are noted in the text. Permission to reproduce those items must be secured from the individual copyright owners.

Published in the Western Region, Menlo Park, California

Manuscript approved for publication, July 8, 2003

Text and illustrations edited by Peter H. Stauffer and James W. Hendley II

Design, layout, and production by Susan E. Mayfield

Cataloging-in-publication data are on file with the Library of Congress (http://www.loc.gov/) 


\section{Contents}

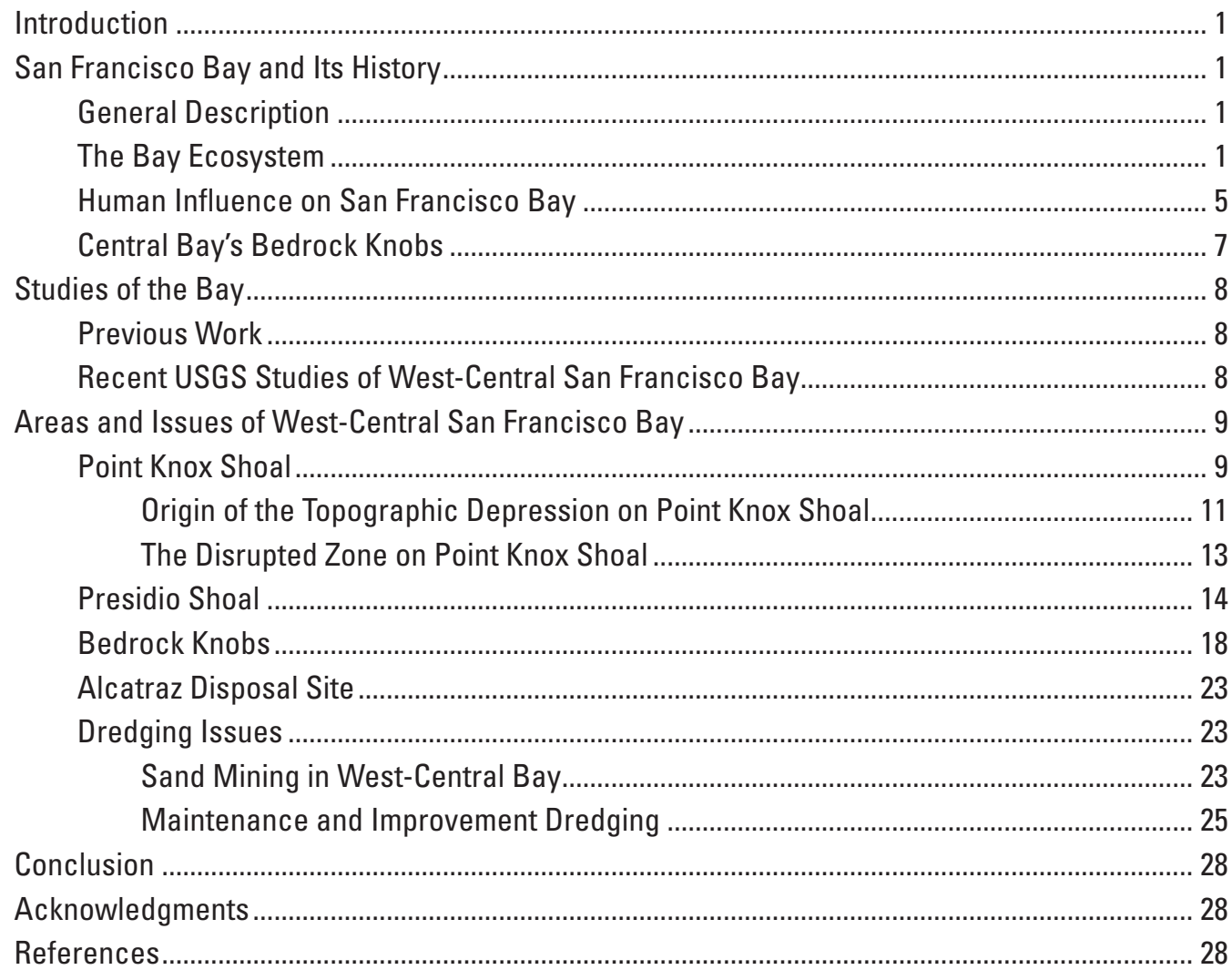




\section{Figures}

1. Map of San Francisco Bay region as it was in the mid-1850's............................................. 2

2. Bathymetric map and shaded-relief image of west-central San Francisco Bay.................... 3

3. Map showing historical changes to the bay margins in the City of San Francisco ................ 4

4. Photograph of mining with high-pressure water cannons in the Gold Rush.......................... 5

5. Bathymetric map of bedrock knobs in San Francisco Bay................................................... 6

6. Sketch of Arch Rock before modification, showing the opening visible at low tide.............. 7

7. Photograph of the blasting of Arch Rock in 1901 ............................................................ 7

8. Diagram of the multibeam sidescan-sonar mapping technique............................................... 8

9. Map showing the bottom types in west-central San Francisco Bay..................................... 9

10. Map showing lease areas for borrow pits on Point Knox Shoal in the 1930's........................ 10

11. Aerial photograph of Treasure Island at the time of the Golden Gate International Exposition... 11

12. Bathymetric profile and map of the borrow area near Alameda......................................... 12

13. Sidescan-sonar imagery of the bay floor in the disturbed zone on Point Knox Shoal............ 13

14. Map of lease areas for sand extraction in west-central San Francisco Bay......................... 15

15. Sidescan-sonar imagery of recent dredge-related features on Point Knox Shoal ................. 16

16. Sidescan-sonar imagery of elongate and circular to semicircular depressions on the periphery of the Point Knox Shoal disrupted zone .............................................................. 17

17. Sidescan-sonar imagery of dredge-related features on Presidio Shoal ................................. 18

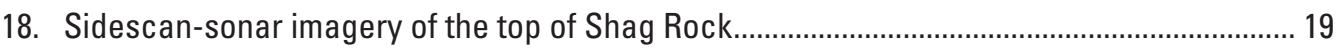

19. Diagram showing the increasing draft of cargo vessels with time......................................... 20

20. Map showing ship lanes for deep-draft vessels in west-central San Francisco Bay ............ 21

21. Photograph of a large container vessel unloading at the Port of Oakland ............................. 22

22. Combination photograph/diagram showing a large oil tanker above and below waterline.. 22

23. Perspective views and cross section showing the evolution of the Alcatraz Disposal Site through time

24. Maps showing the original extent of wetlands in the Bay-Delta region and what has happened to them

\section{Map Supplement and 3-D glasses}

[In pocket]

Under San Francisco Bay-A new view of the floor of west-central San Francisco Bay 


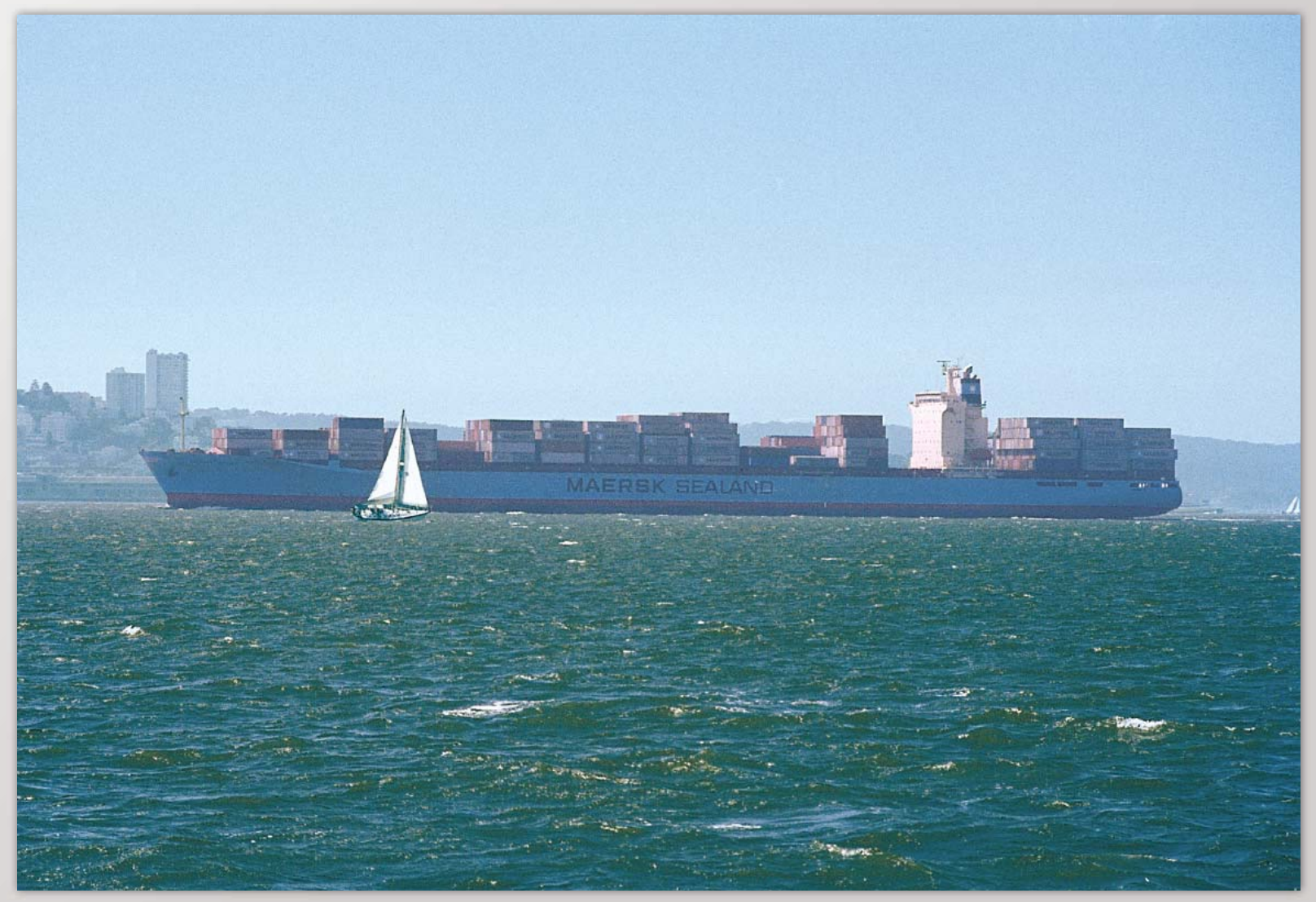

A large container ship traveling in the eastbound vessel-traffic lane in the vicinity of submerged Blossom Rock as it begins to pass between Treasure Island and downtown San Francisco on its way to the Port of Oakland. (USGS Photograph by Michael F. Diggles.) 


\title{
Shifting Shoals and Shattered Rocks-How Man Has Transformed the Floor of West-Central San Francisco Bay
}

\author{
By John L. Chin, Florence L. Wong, and Paul R. Carlson
}

\section{Introduction}

San Francisco Bay, one of the world's finest natural harbors and a major center for maritime trade, is referred to as the "Gateway to the Pacific Rim." The bay is an urbanized estuary that is considered by many to be the major estuary in the United States most modified by man's activities (Nichols and others, 1986). The population around the estuary has grown rapidly since the 1850's and now exceeds 7 million people. The San Francisco Bay area's economy ranks as one of the largest in the world, larger even than that of many countries. More than 10 million tourists are estimated to visit the bay region each year (San Francisco Convention and Visitors Bureau, unpub. data accessed online August 21, 2002 at http://www.sfvisitor.org). The bay area's population and associated development have increasingly changed the estuary and its environment.

San Francisco Bay and the contiguous Sacramento-San Joaquin Delta encompass roughly 1,600 square miles $\left(4,100 \mathrm{~km}^{2}\right)$ and are the outlet of a major watershed that drains more than 40 percent of the land area of the State of California (fig. 1). This watershed provides drinking water for 20 million people (twothirds of the State's population) and irrigates 4.5 million acres of farmland and ranchland (Friends of the Estuary, 1997).

During the past several decades, much has been done to clean up the environment and waters of San Francisco Bay. Conservationist groups have even bought many areas on the margins of the bay with the intention of restoring them to a condition more like the natural marshes they once were. However, many of the major manmade changes to the bay's environment occurred so long ago that the nature of them has been forgotten (Nichols and others, 1986). In addition, many changes continue to occur today, such as the introduction of exotic species and the loss of commercial and sport fisheries because of declining fish populations. The economy and population of the nine counties that surround the bay continue to grow and put increasing pressure on the bay, both direct and indirect. Therefore, there are mixed signals for the future health and welfare of San Francisco Bay.

The San Francisco Bay estuary consists of three subembayments — north bay (San Pablo and Suisun Bays), central bay, and south bay — each characterized by a central area of open water surrounded by intertidal mudflats and marshes (fig. 1). Central bay includes Alcatraz and Angel Islands and also a number of submerged bedrock knobs that protrude through the sediment of the bay floor and rise to within about 40 feet (12 m) of the water surface (fig. 2 and map supplement). The most prominent of these are Harding, Shag, Arch, and Blossom Rocks. These rocks have been lowered by blasting several times in the past, but they remain a potential hazard to shipping because newer cargo vessels are designed with increasingly deeper drafts. Central bay's location adjacent to two major population and commerce centers, San Francisco and Oakland, subjects it to greater human influences than less developed parts of the estuary. The western part of central San Francisco Bay is adjacent to the Golden Gate, the estuary's outlet to the Pacific Ocean. The changing submarine topography of the west-central bay, as well as its geology, form the main focus of this book.

\section{San Francisco Bay and Its History General Description}

San Francisco Bay and its several subembayments form a large estuarine system. The average water depth of the San Francisco Bay estuary as a whole is 20 feet $(6 \mathrm{~m})$ mean lower low water (MLLW; the average height of the lower of the two daily low tides, used as a standard reference plane for hydrographic surveys and charts) (Conomos, 1979). The Golden Gate attains a maximum depth of approximately 330 feet $(100 \mathrm{~m})$. Strong tidal currents flow through the Golden Gate, sweeping away mud and fine sediment. This winnowing makes the floor of central bay generally coarser in sediment texture than the other bays (Rubin and McCulloch, 1979). South and north bays have an average depth of 10 to 13 feet (3-4 m) MLLW, with relatively deep tidal channels 30 to 65 feet (9-20 m) MLLW. Central bay in contrast has an average water depth of 36 feet (11 m) MLLW, about 3 times that of south and north bays. Because of its greater average water depth, central bay also has the largest water volume, even though its surface area is less than half that of south bay (The Bay Institute, 1998).

\section{The Bay Ecosystem}

Roughly 200 years ago, the San Francisco Bay estuarine system was a rich, complex, and diverse ecological habitat teeming with a large variety of wildlife both above and below its waters (The Bay Institute, 1998). Tidal marshes occupied about 


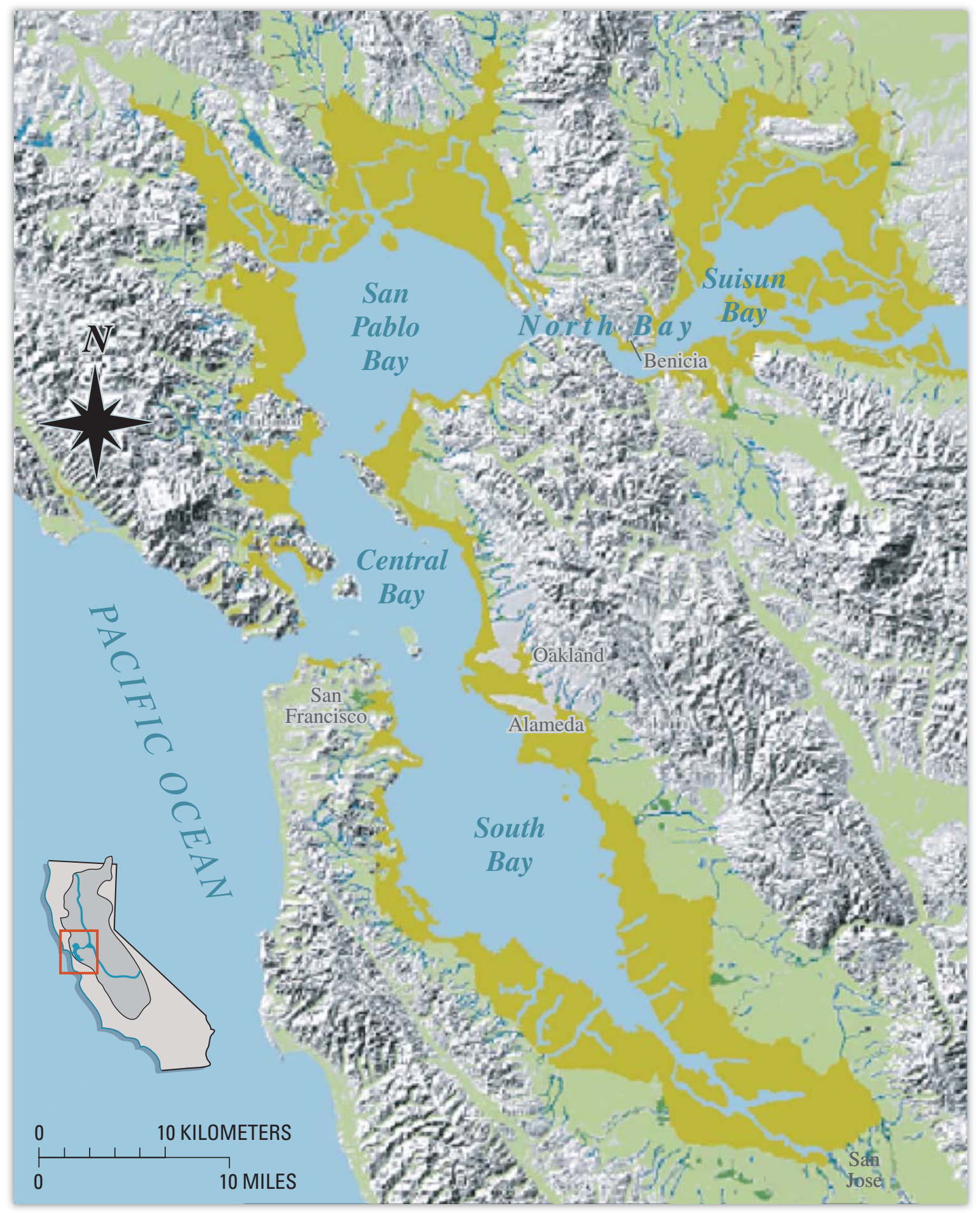

Figure 1. San Francisco Bay, one of the world's finest natural harbors, consists of three subembayments-north bay (San Pablo and Suisun Bays), central bay, and south bay-each characterized by a central area of open water surrounded by intertidal mudflats and marshes. This map shows the bay region as it was in the mid-1850's, before development-areas in yellow-green along the margins of the bay are "baylands" (lands that lie between the elevations of high and low tides) that were present then. The population of the region has grown rapidly since the 1850's and now exceeds 7 million people. The bay is an urbanized estuary, perhaps the major estuary in the United States most modified by man's activities. This explosive development has increasingly changed the estuary and its environment. Inset map shows the 40 percent of California that drains through the Sacramento and San Joaquin Rivers into San Francisco Bay. (Modified from Goals Project, 1999; original map from Bay Area EcoAtlas @ 1999 San Francisco Estuary Institute.) 


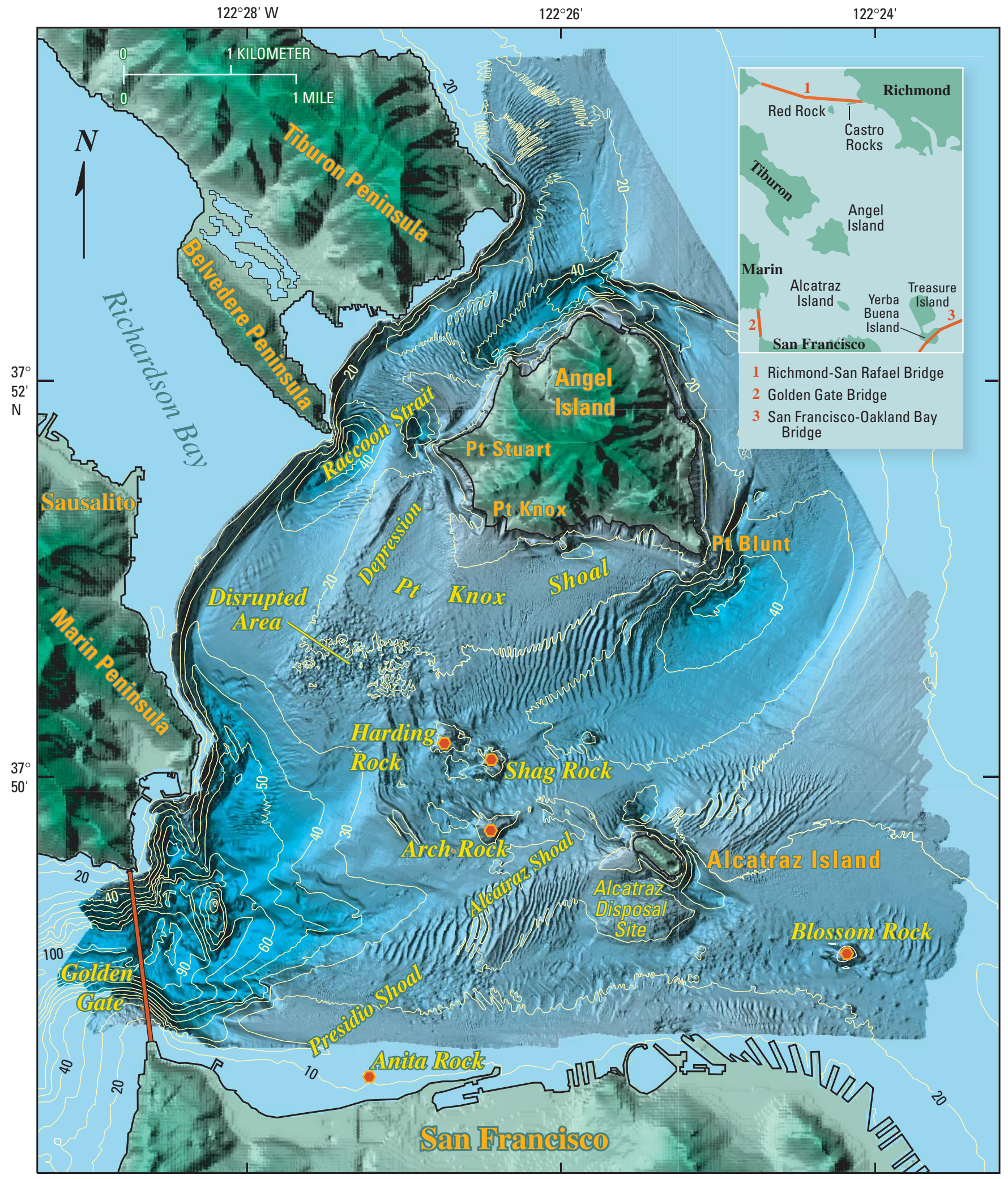

Figure 2. Bathymetric map and shaded-relief image of west-central San Francisco Bay generated from geographically corrected data obtained on 1997 U.S. Geological Survey (USGS) multibeam survey $(95 \mathrm{kHz})$, with the artificial illumination from the northwest. This image was digitally merged with a shaded-relief image for land areas derived from a USGS digital elevation model (DEM) having 30-m resolution. Inset shows setting of this area within central bay. Red bold lines are major bridges. Bathymetric contours in meters, contour interval $10 \mathrm{~m}$ (about 33 feet; 1 meter=3.281 feet). Red dots indicate bedrock knobs. 


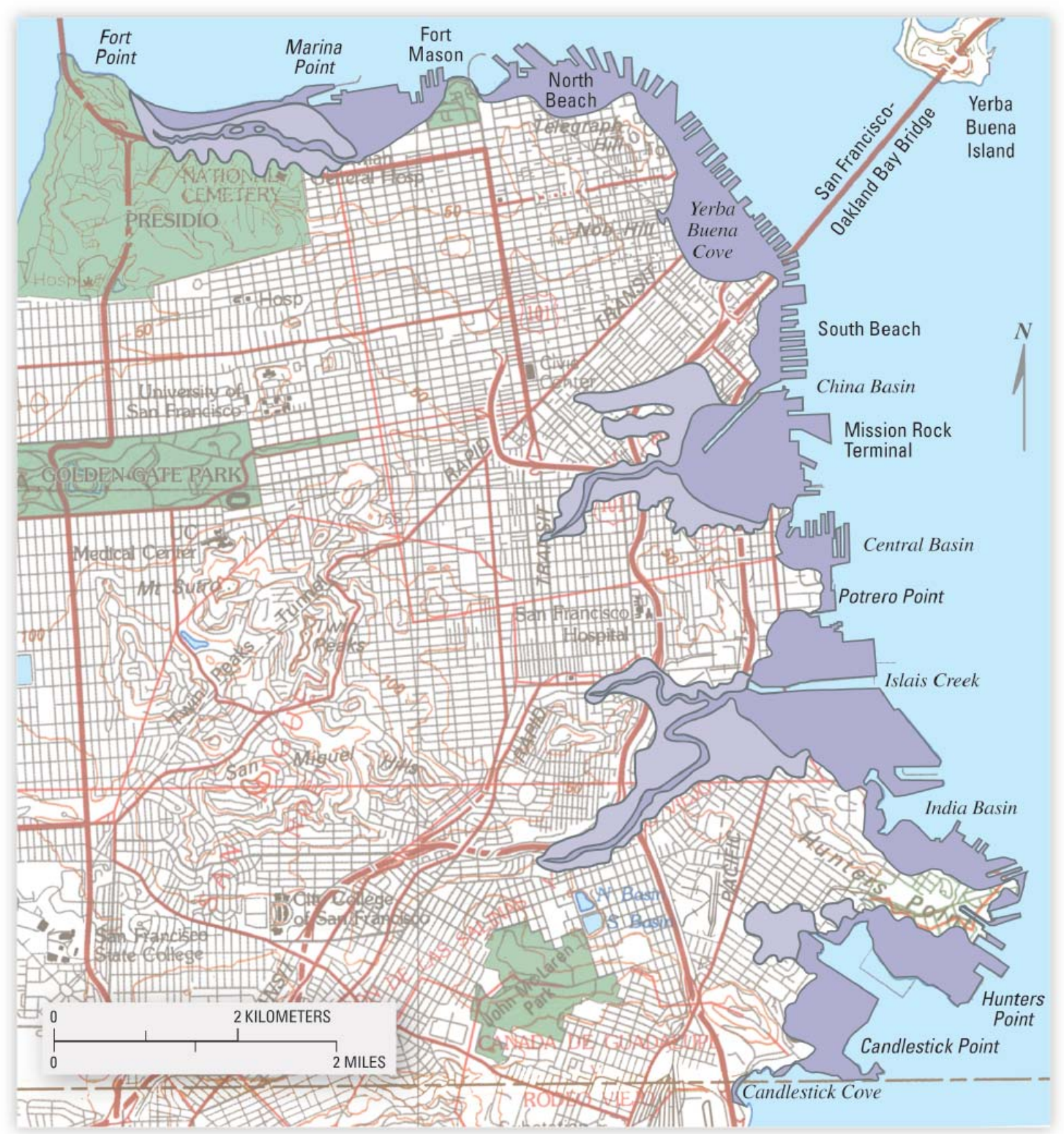

Figure 3. Historical changes to the bay margins in the City of San Francisco. Light purple, tidal marshlands that have been filled since 1847. Dark purple, open water areas filled since 1847. (Modified from Dow, 1973; base map is USGS San Francisco Quadrangle 1:100,000-scale topographic map, 1978 edition.)

200,000 acres (80,000 ha) along the bay's margins in the early 1800's (Goals Project, 1999). Many of these were large contiguous tidal marshes, particularly in the north and south bays. Today, the tidelands (lands between high and low tides) provide food, shelter, and other benefits to more than 500 species of fish, amphibians, reptiles, birds, and mammals. If invertebrates, such as clams, crabs, and insects, are included, far more than 1,000 animal species can be found in the tidelands ecosystem. The economic value of these tidal wetlands in the San Francisco Bay area alone is a major part of the annual economic value of wetlands for the State of California, which is estimated to be at least $\$ 6.3$ billion (Goals Project, 1999).
San Francisco Bay is also the inland migration route for about 75 percent of the salmon harvested offshore California and for as much as 50 percent of Oregon's catch. It supports the largest Pacific coast herring fishery south of British Columbia, is the nursery habitat for the Dungeness crab, and provides important fish habitat for other species such as English sole, California halibut, and striped bass (Pacific Coast Federation of Fisherman's Associations, 1997). In the past, millions of birds used San Francisco Bay as part of their migration on the Pacific Flyway. Even now, San Francisco Bay is known as a major North American refuge for many species of shorebirds and waterfowl during their migration and wintering periods. 


\section{Human Influence on San Francisco Bay}

San Francisco Bay has been called the "centerpiece of life" in the bay area-heavily interwoven with the politics, economics, social structure, and esthetics of the region (Kelley, 1998). To determine how man has influenced San Francisco Bay, both review of historical documents and direct observations are required. For example, a map in Dow (1973) reviewing historical evidence of manmade changes between 1847 and 1972 shows the extensive alterations of the baylands along the northern and eastern shores of the San Francisco peninsula and other areas bordering central and southern San Francisco Bay. The waterfront acreage of San Francisco was increased significantly by filling tidelands and in some cases shallow coves and lagoons (fig. 3). Fill material included sand dredged from nearby Presidio Shoal, abandoned ships from the Gold Rush of the mid-1800's, and debris from buildings that had been demolished in the 1906 earthquake. Chameau and others (1991) estimated that development of the San Francisco waterfront required more than 410 million cubic feet $\left(11.7\right.$ million $\mathrm{m}^{3}$ ) of fill during the period 1845 to 1920 .

Although San Francisco Bay has experienced manmade modifications for centuries, man's influence on the environment has increased significantly in both degree and scope over the past 150 years. Until the mid-1800's, indigenous people and the few European settlers had minimal effect on the bay's environment, but this changed with the 1848 discovery of gold in the foothills of the Sierra Nevada, about 100 miles to the northeast. The resulting Gold Rush brought about a great influx of people to the bay area. Many of the new immigrants to California arrived by boat and disembarked at ports in the bay, especially the burgeoning city of San Francisco. In 1776, well before the Gold Rush, the European population of California numbered only about 80 , but by the time of the first State census in 1860, that population had grown to 380,000 (Kelley, 1998). The rapid rise in population resulting from the influx of miners, merchants, and other camp followers placed great demands on the entire watershed, including San Francisco Bay and its margins.

Modifications that have affected the floor of west-central San Francisco Bay include the lowering of the tops of bedrock knobs, dredging of harbors and waterways, filling of tidelands, artificial filling on Yerba Buena Shoal to create Treasure Island, dredging of sand shoals, and unintended shoaling due to the accumulation of Gold Rush hydraulic mining debris. Many of the modifications made over the past 150 years are essentially permanent, as natural processes or human efforts are unlikely to return the environment to its former state.

An example of such irreversible changes is the shoaling caused by the influx of hydraulic mining debris from the Sierra foothills (fig. 4). Hydraulic mining excavated and dislocated roughly 1.4 billion cubic yards $\left(1.1\right.$ billion $\mathrm{m}^{3}$ ) of material from ore deposits; this volume of material was 8 times that removed for the construction of the Panama Canal (The Bay Institute, 1998). Gilbert (1917) estimated that enough sediment (mining debris) made it into San Francisco Bay by the end of the 19th century to cause the vertical accretion of tidal mudflats- 3.3 feet $(1.0 \mathrm{~m})$ in Suisun Bay, 2.5 feet $(0.75 \mathrm{~m})$ in San Pablo Bay, and 0.7 feet $(0.25 \mathrm{~m})$ in Central Bay. This influx of debris reduced the tidal prism (the volume of tidal flow) of the entire estuary and altered the tidal circulation patterns in the bay. Because vast quantities of hydraulic mining debris from the Gold Rush are still found in much of the watershed, such debris will continue to erode and be deposited in the estuary for a very long time.

The influx of hydraulic mining debris significantly hastened the natural sedimentation process and contributed to a permanent reduction of the open water area of San Francisco Bay (Nichols and others, 1986). By the 1970's, roughly 95 percent of the natural wetlands in the bay and delta were lost to man's activities. The Bay Institute (1998) further documents that 79 percent of tidal marshes in the bay were reclaimed for other uses and 42 percent of tidal mudflats were lost to man's activities.

The rapid expansion of commerce that accompanied the Gold Rush relied heavily on water-borne transport (The Bay Institute, 1998). Following a trend that still holds today, increasing maritime commerce brought about the need not only for more vessels but also for larger vessels of greater draft to handle the increasing volume of goods. Ship traffic required waterways where water depths were maintained at safe levels and hazards were removed or mitigated. In 1868, the San Francisco Channel, the first Federal navigation project in the bay, was constructed in response to this need. This project marked the advent of the Federal Government's involvement in maritime safety issues and waterways in the estuary.

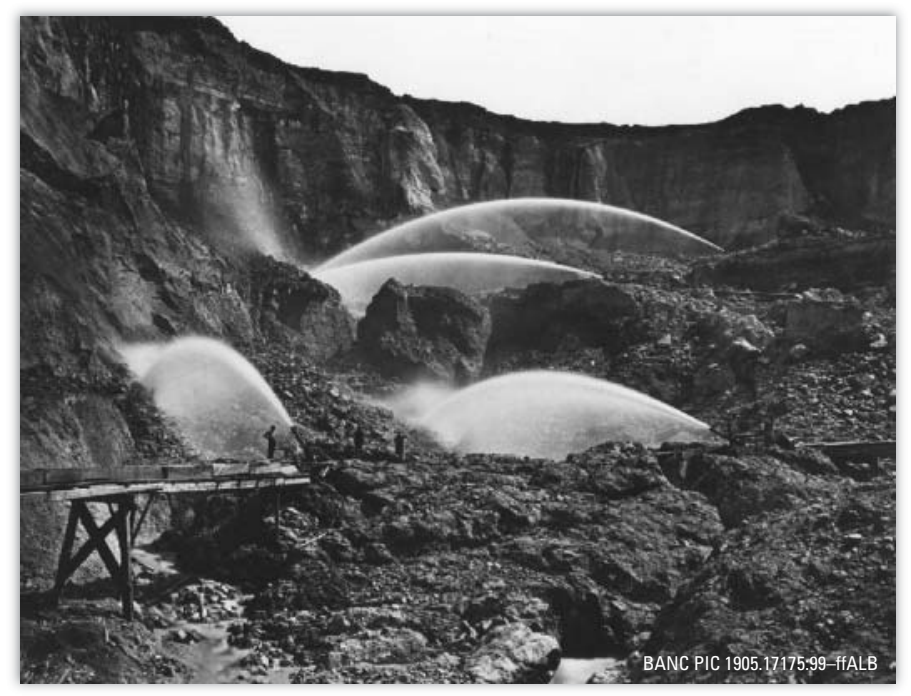

Figure 4. The Gold Rush of the 19th century caused a population explosion in California and led to the first major manmade changes to the region's landscape. This photograph shows highpressure water cannons (monitors) washing down gold-bearing gravel at the Malakoff Diggings in the foothills of the Sierra Nevada. Such destructive hydraulic mining methods, later outlawed in California, sent enormous quantities of sediment down the rivers and into San Francisco Bay, where it reduced the water depth over large areas. (Photograph by Carleton E. Watkins, courtesy of the Bancroft Library, University of California, Berkeley.) 


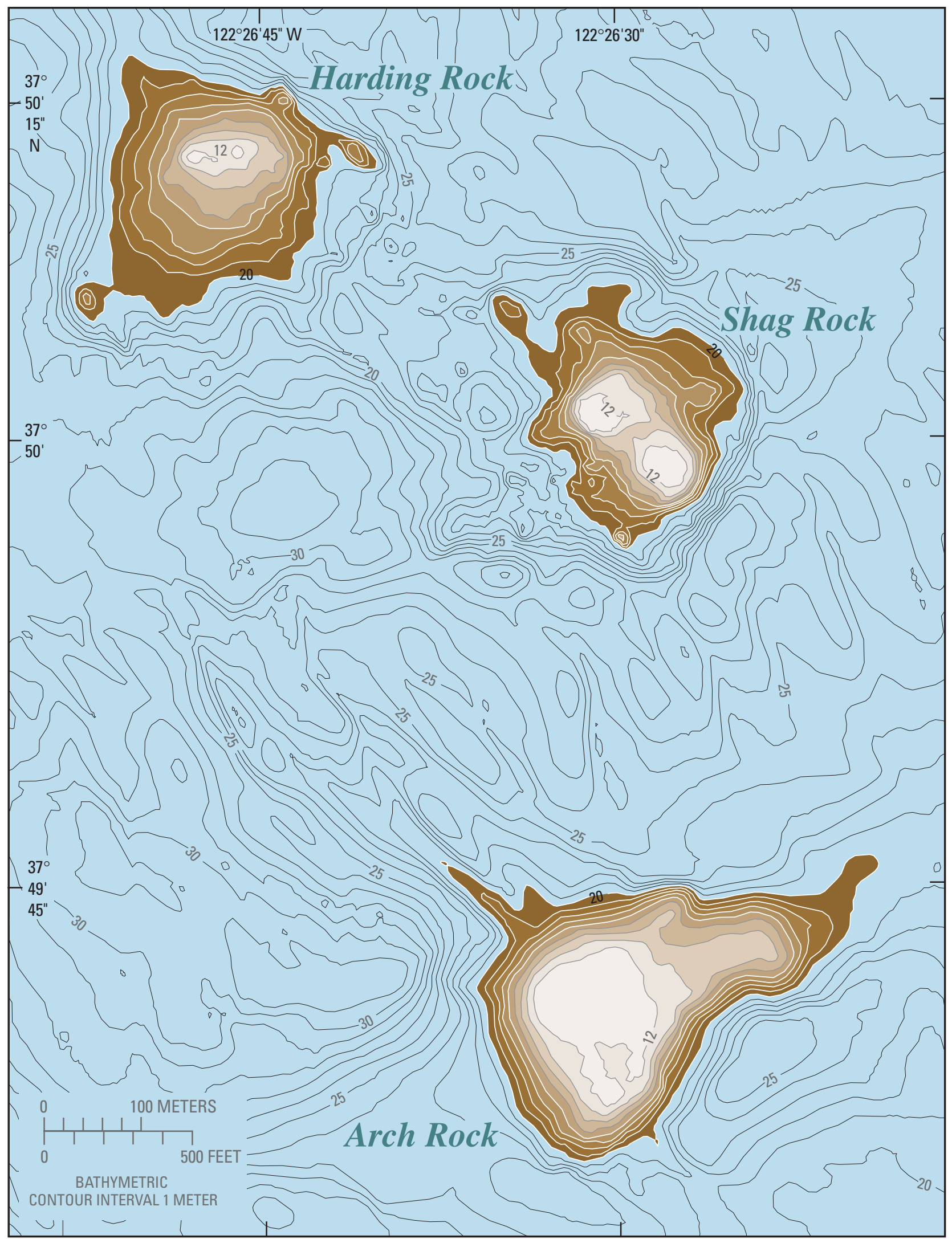

Figure 5. Bathymetry (water depths) over Harding, Shag, and Arch Rocks. Depths in meters corrected to MLLW (mean lower low water; the average height of the lower of the two daily low tides); contour interval is $1 \mathrm{~m}$ ( 1 meter $=3.281$ feet). Areas shallower than $20 \mathrm{~m}$ (66 feet) shown in brown shades. Data from 1997 U.S. Geological Survey multibeam (95 kHz) survey. 


\section{Central Bay's Bedrock Knobs}

Central San Francisco Bay is characterized by a number of submerged rock knobs that rise above the surrounding bay floor. Several of these rock knobs posed a serious hazard to navigation and have been lowered by blasting in the past. West-central San Francisco Bay in particular has several such rock knobs, some of which have been named-Anita, Blossom, Harding, Shag, and Arch Rocks (fig. 2). In addition, the emergent Red Rock and Castro Rocks are found in the northern part of central bay, near the Richmond-San Rafael Bridge. All these rock knobs in central San Francisco Bay are believed to be part of the same geological formation, the Franciscan Complex. This heterogeneous rock assemblage of Jurassic-Cretaceous age (190 to 65 million years old) is the bedrock beneath much of the San Francisco Bay area (Konigsmark, 1998). Franciscan rocks form Yerba Buena, Angel, and Alcatraz Islands, as well as many of the hills of San Francisco and the Marin Headlands adjacent to the Golden Gate.

Harding, Shag, Arch, and Blossom Rocks all occur in a general northwest-southeast line that coincides with the orientation and position of Alcatraz Island (fig. 2), suggesting that they may be part of a continuous bedrock ridge (Carlson and others, 2000). This structural ridge is highly irregular and trends roughly parallel to the Tiburon Peninsula and to other ridges in the Coast Range, as well as to major faults in the region (Carlson and others, 2000). Harding Rock rises to within about 40 feet (12 m) MLLW of the water surface and is characterized by three small individual knobs that form the shallowest part of the rock mass (fig. 5). According to an 1854 U.S. Coast and Geodetic Survey chart (Sheet no. 2, Register no. 462, "Bay of San Francisco"), Shag Rock then shoaled at 23 feet $(7 \mathrm{~m})$. The present top of Shag Rock is oval to rectangular in shape with two relatively flat areas, both at 40 feet (12 m) MLLW (fig. 5). Arch Rock is currently the shallowest of the rocks adjacent to Alcatraz Island, with its top shoaling at about 36 feet (11 m) MLLW (fig. 5). Its shape is somewhat rectangular and its top relatively flat. Blossom Rock shoals at about 40 feet $(12 \mathrm{~m})$ MLLW.

The likely "natural" condition of these bedrock knobs, as evidenced by Angel and Yerba Buena Islands and by unmodified rock knobs, such as Red Rock, is a pointed or rounded peak. Before it was lowered by blasting, Arch Rock projected above water as a sharp cone, with a large opening through it (hence the name) visible at low tide (fig. 6). The relatively flat top of Alcatraz Island is known to be a result of man's modifications since the 1800's. All the flat tops of the submerged rock knobs in west-central San Francisco Bay probably have a similar origin.

The increase in vessel drafts in the decades following the Gold Rush raised concerns about the ability of these larger ships to safely transit through west-central San Francisco Bay (Carlson and others, 2000). Blossom Rock rose to within 5 feet $(1.5 \mathrm{~m})$ of the water surface at low tide in 1867 and was considered a hazard to safe navigation (Hagwood 1982). The U.S. Army Corps of Engineers (USACE) began lowering the top of Blossom Rock in that year and by 1870 had lowered it to 24 feet $(7.3 \mathrm{~m})$ below the water surface.
In 1898, USACE recommended that Blossom, Shag, and Arch Rocks be lowered to a depth of 30 feet (9 m) MLLW for safe navigation. Description of the work indicates that the two flat areas that characterize the top of Shag Rock ("Shag 1 and Shag 2") were blasted in 1900 (Hagwood, 1982). Arch Rock was blasted in 1901 (fig. 7), and work was completed in 1902. Lowering of Blossom Rock occurred in 1902 and 1903. Until about 1916, USACE continued to lower the "worst" of the submerged rock knobs by blasting. Waterway development for safe navigation continued in the 1930's. By the mid-1930's Harding, Shag, and Arch Rocks had also been lowered to 36 feet (11 m) MLLW (Hagwood, 1982).

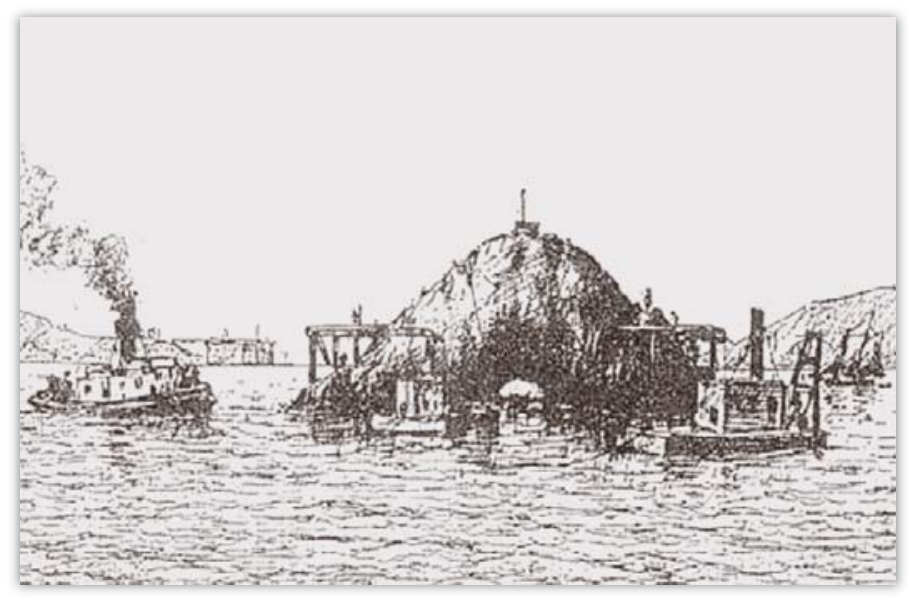

Figure 6. Sketch of Arch Rock (with the Golden Gate in the background) around 1900, before it was blasted away as a hazard to navigation. The opening through the rock was visible only at low tide, and navigating small boats through it provided a challenge to daring souls. The death of one such adventurer helped seal the rock's fate. (Image courtesy of U.S. Army Corps of Engineers.)

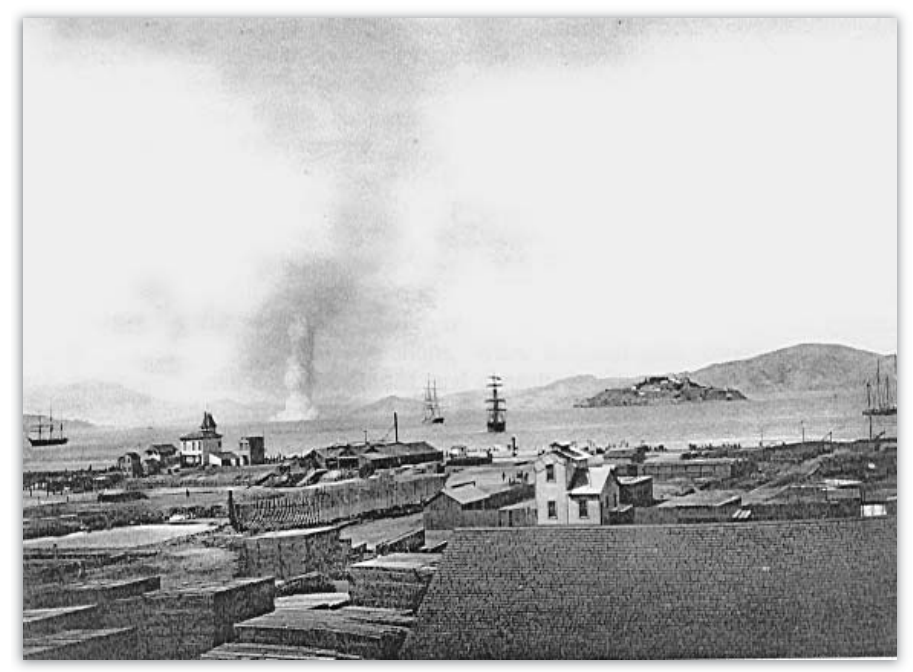

Figure 7. Blasting of Arch Rock in 1901 is seen in this photograph taken from San Francisco. Alcatraz Island is in the right middle ground. (Photograph courtesy of U.S. Army Corps of Engineers.) 


\section{Studies of the Bay}

\section{Previous Work}

A great number of the scientific studies documenting man's impact on San Francisco Bay have focused on the biology, hydrology, and chemistry of the estuary's waters and its tidelands. With the exception of Gilbert's (1917) investigation of the effects of hydraulic mining debris on the watershed and estuary, few investigations have focused on man's impact on and physical modification of the floor of San Francisco Bay. Comprehensive compilations on San Francisco Bay and its watershed include Gilbert (1917), Conomos (1979), Nichols and others (1986), The Bay Institute (1998), and Goals Project (1999). The adjacent tidelands, which have undergone profound modifications by man's activities since the Gold Rush era, were studied by Nichols and Wright (1971), Dow (1973), and Atwater (1979), among many others. Investigations that at least partially deal with central San Francisco Bay and with man's impact on the bay floor include Gilbert (1917), Carlson and McCulloch (1970), Carlson and others (1970), Cruickshank and Hess (1975),

Nichols (1979), Rubin and McCulloch (1979), Chin and Clifton (1990), Clifton and others (1991), Chin and others (1997), Chin and others (1998), and Carlson and others (2000).

\section{Recent USGS Studies of West-Central San Francisco Bay}

Some of the major challenges specific to west-central San Francisco Bay include the issues surrounding potential further lowering of bedrock knobs (Harding, Shag, Arch, and Blossom Rocks), sand mining for aggregate material, and dredging for maintenance and improvement of waterways and harbors. All of these challenges are rooted in both economic and political issues of the San Francisco Bay region, and their resolution will affect the region's overall future. Although environmental and regulatory policies are in place, Nichols and others (1986) noted that economically important issues (including deepening of ship channels) have in some instances been considered without sufficient scientific understanding of the effects on the estuary.

For this reason, the U.S. Geological Survey (USGS) conducted detailed studies of west-central San Francisco Bay in the late 1990's. These studies revealed details of bottom features in the area and shed light on the natural and manmade processes that have influenced them, providing information essential to resolving the issues concerning the bay. Cooperative surveys by the USGS and the National Oceanic and Atmospheric Administration (NOAA) in 1997 were contracted to C\&C Technologies (Lafayette, Louisiana). USGS surveys in 1998 and 1999 were

Figure 8. The U.S. Geological Survey shaded-relief image of the floor of west-central

San Francisco Bay (fig. 2) was created from data obtained in 1997 using a multibeam swath bathymetry system, which is a variety of sidescan sonar. In this multibeam system, diagramed here, a hull-mounted transducer sends sound energy toward the sea floor and receives back reflected sound through multiple narrow beams. As the ship moves forward (toward the lower left in the diagram), it maps a swath of sea floor. The record or image created on the shipboard recorder has the ship's direction as one axis and the distance between the transducer and the bottom ("slant range") as the other axis. Strong returned signals ("high backscatter") form dark areas on the image; weak signals ("low backscatter") form light areas. The first signal returned is from directly below the ship, and its slant range is equal to the water depth below the transducer. Traditional sidescan-sonar systems produce similar images (see figs. 13 and 15-18), but because the transducer is towed behind the ship, data are not precisely referenced as to location and water depth. Uncorrected images produced by any sidescan-sonar system contain distortions of scale and shape, both because of variations in the ship's forward speed and because of the varying angles of the slant-range distances. Image-processing software can remove these distortions and produce a geographically correct image, such as that in figure 2. The 1997 survey was operated from the C\&C Technologies vessel Coastal Surveyor (seen in the inset photograph with the semicircular multibeam sound transducer raised above water-during operations the transducer is lowered into the water).

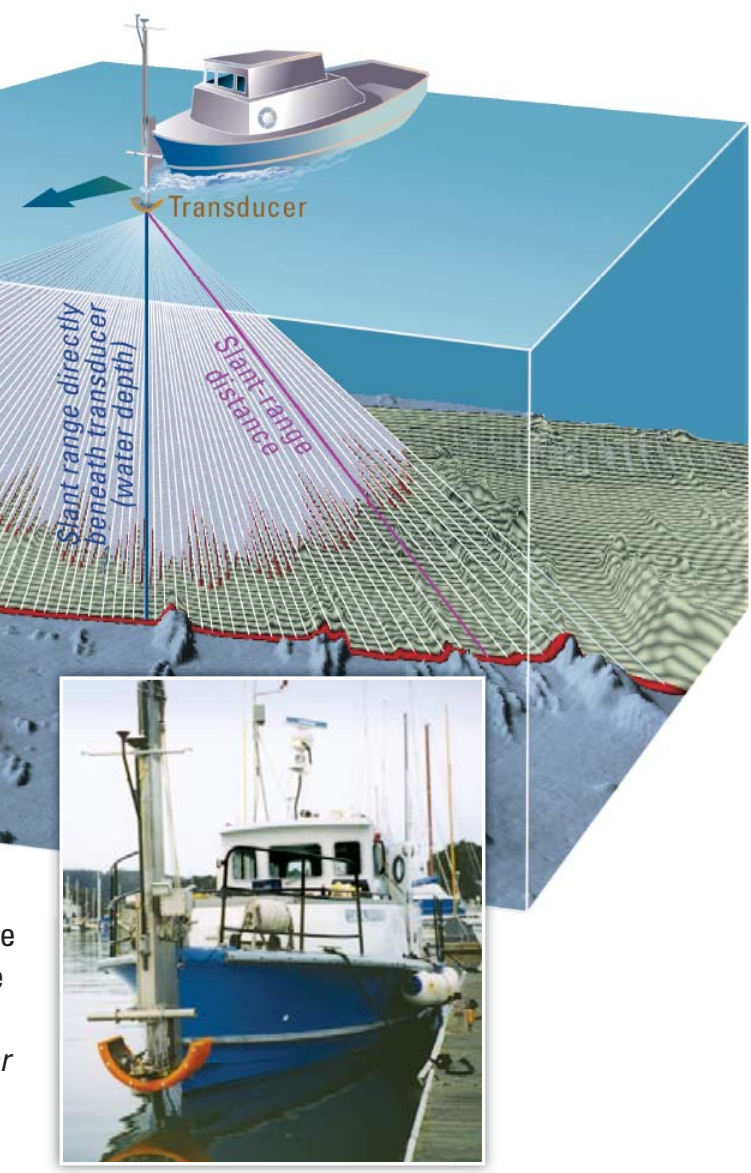


done using the research vessel RV David Johnston. Navigation on all surveys was based on differential global positioning systems (DGPS). The nominal horizontal accuracy obtained using DGPS was on the order of 3 feet $(1 \mathrm{~m})$. Vertical accuracy of acoustic data was 0.3 to 0.6 feet $(0.1-0.2 \mathrm{~m})$.

Acoustic data were obtained with two different instrument systems. On the 1997 surveys, a Simrad EM-1000 multibeam swath bathymetry system was used to image the bay floor (fig. 8). Approximately 17.5 square miles $\left(45 \mathrm{~km}^{2}\right)$ of the bay floor was imaged using the multibeam system. This system simultaneously acquired spatially coregistered bathymetric and backscatter data at a frequency of $95 \mathrm{kHz}$. Tracklines were run with 100 percent overlap so as to produce a continuous mosaic of the area (fig. 2).

A Klein sidescan-sonar system was used on the 1998 and 1999 surveys to obtain acoustic imagery. The Klein sidescansonar imagery was collected to field check observations and interpretations that had been made from the 1997 multibeam data. The operating frequency of the sidescan system was 100 $\mathrm{kHz}$, with a range of 330 feet $(100 \mathrm{~m})$.

\section{Areas and Issues of West-Central San Francisco Bay}

West-central San Francisco Bay, as shown by a USGS shaded-relief image generated from data collected on a 1997 survey (fig. 2), is the deepest part of the bay and is charac-

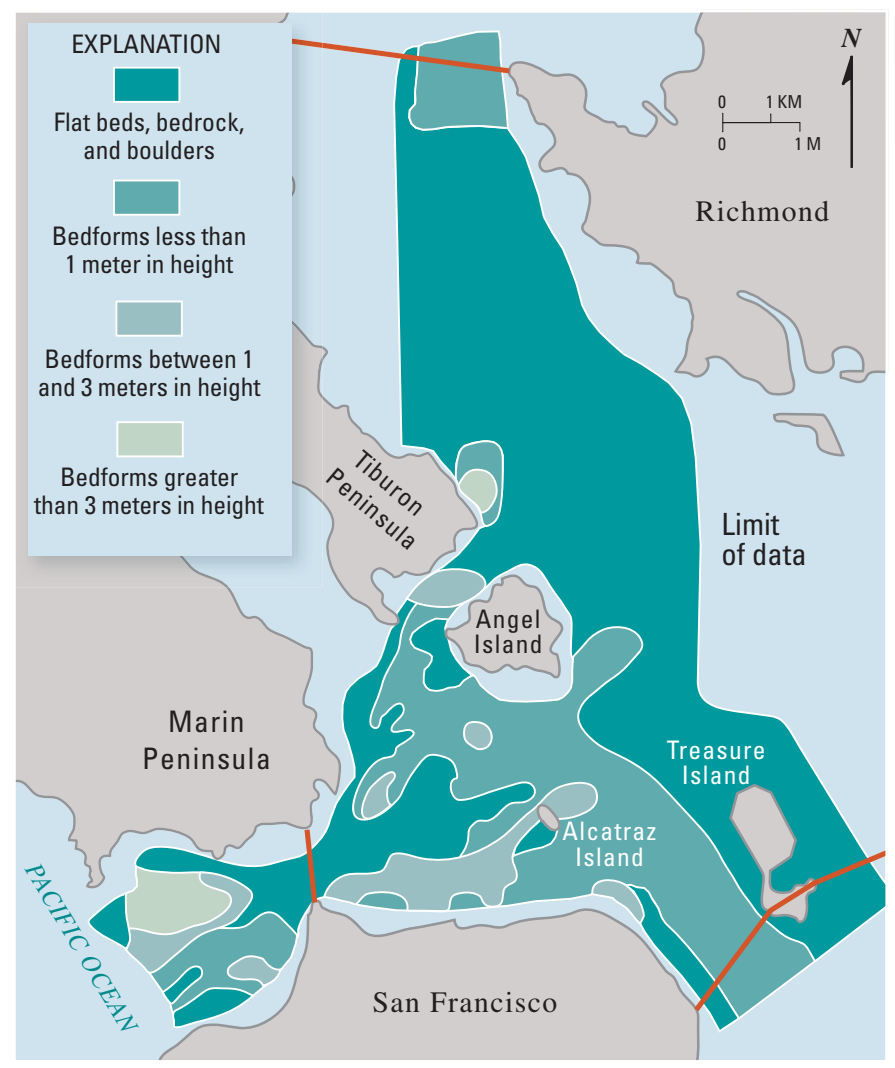

terized by the coarsest sediment in the entire estuary. The bay floor is molded into a variety of topographic features (bedforms) that are the result of the interaction of sediment, tidal currents, and water depth, as well as the influence of human activities.

USGS scientists Rubin and McCulloch (1979) documented naturally occurring bedforms and bottom types in central San Francisco Bay using sidescan-sonar imagery (100 $\mathrm{kHz}$ frequency). They delineated three basic bottom types in the central bay—bedforms (in three size ranges), "flat beds," and bedrock or boulders (fig. 9).

The bedforms consist primarily of sand waves (if ripples were present, their size was below the 0.3- to 0.6-foot (0.1-0.2 $\mathrm{m})$ resolution limit of the sidescan-sonar system used). The sand waves were subdivided into three classes on the basis of their heights-less than 3 feet ( $1 \mathrm{~m}), 3$ to 10 feet (1-3 m), and greater than 10 feet $(3 \mathrm{~m}$ ) (fig. 9). Sand waves covered roughly half of the area surveyed in central bay in 1979.

The second most abundant bottom type mapped in 1979 in central bay was "flat beds," areas that appear flat in sidescan imagery because any irregularities were less than 0.3 feet $(0.1$ $\mathrm{m}$ ) high, below the resolution limit of the sidescan system. Flat beds included both areas of relatively smooth sediment cover and flat areas of exposed bedrock.

The third bottom type, bedrock and boulders, was mapped primarily in the vicinity of the Golden Gate. In this area, the bay floor is continually swept clear of sediment by high-velocity tidal currents, keeping boulders and rock exposed.

Rubin and McCulloch's (1979) map of bay-floor bottom types of central San Francisco Bay provides a baseline for detecting subsequent changes in bottom types and features resulting from man's activities. The map encompasses the entire area that was later surveyed by the USGS in the 1990's and is the subject of this paper. These USGS studies focused on several areas and issues of west-central San Francisco Bay, including Point Knox Shoal, Presidio Shoal, bedrock knobs, the Alcatraz Disposal Site, and dredging.

\section{Point Knox Shoal}

Point Knox Shoal forms an arcuate submerged topographic high extending to the southwest from Angel Island between Points Stuart, Knox, and Blunt (fig. 2). Water depths over the shoal range from about 20 to 65 feet $(6-20 \mathrm{~m})$. The southeastern margin of the shoal is characterized by sand waves that trend approximately north-south and are roughly 3 to 6 feet $(1-2 \mathrm{~m})$ in height with a wavelength of 100 to 200 feet (30-60 m). At their

Figure 9. Sidescan-sonar surveys in the 1970's delineated areas of the bottom in west-central San Francisco Bay characterized by bedrock, boulders, flat sediment, and bedforms. Bedforms are mainly sand waves and dunes. Red lines are bridges-see figure 2. (Map modified from Rubin and McCulloch, 1979.) 


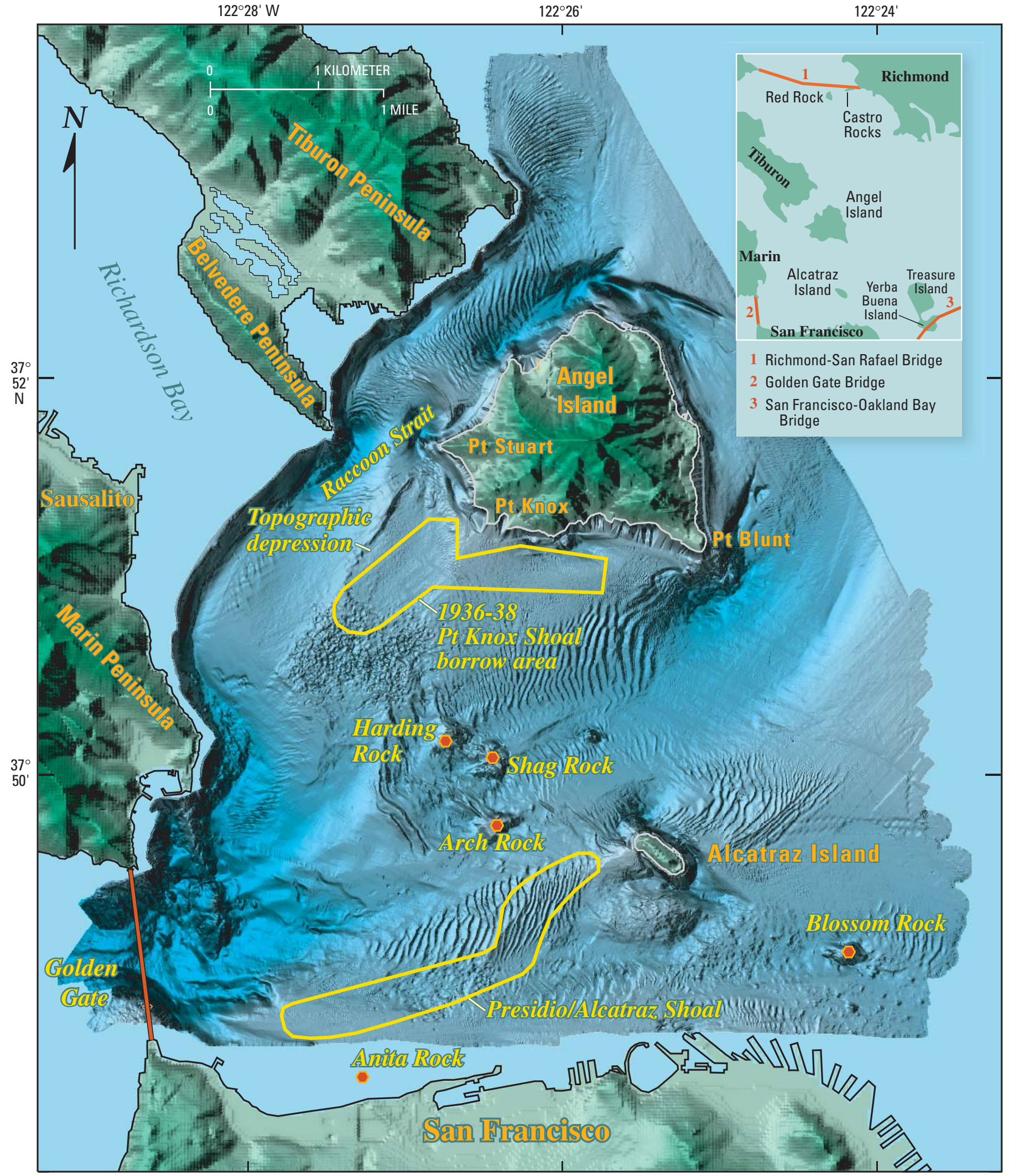

Figure 10. Shaded-relief image of west-central San Francisco Bay (see fig. 2), showing borrow areas used during 1936-38 to provide dredged material for constructing Treasure Island. Note that the topographic depression in the present bay floor southwest of Angel Island largely coincides with the western part of the 1936-38 borrow site on Point Knox Shoal. (Multibeam shaded-relief image of bay floor by U.S. Geological Survey, 1997; borrow areas from Cruickshank and Hess, 1975.) 
Figure 11. Aerial photograph of Treasure Island and the 1939 Golden Gate International Exposition. Treasure Island was built up entirely by filling in a shallow area of San Francisco Bay north of Yerba Buena Island (right). The eastern half of the San Francisco-Oakland Bay Bridge in the background leads to Oakland and the East Bay. The Golden Gate International Exposition celebrated the completion of the Bay Bridge in 1936 and the Golden Gate Bridge in 1937. Part of Treasure Island served

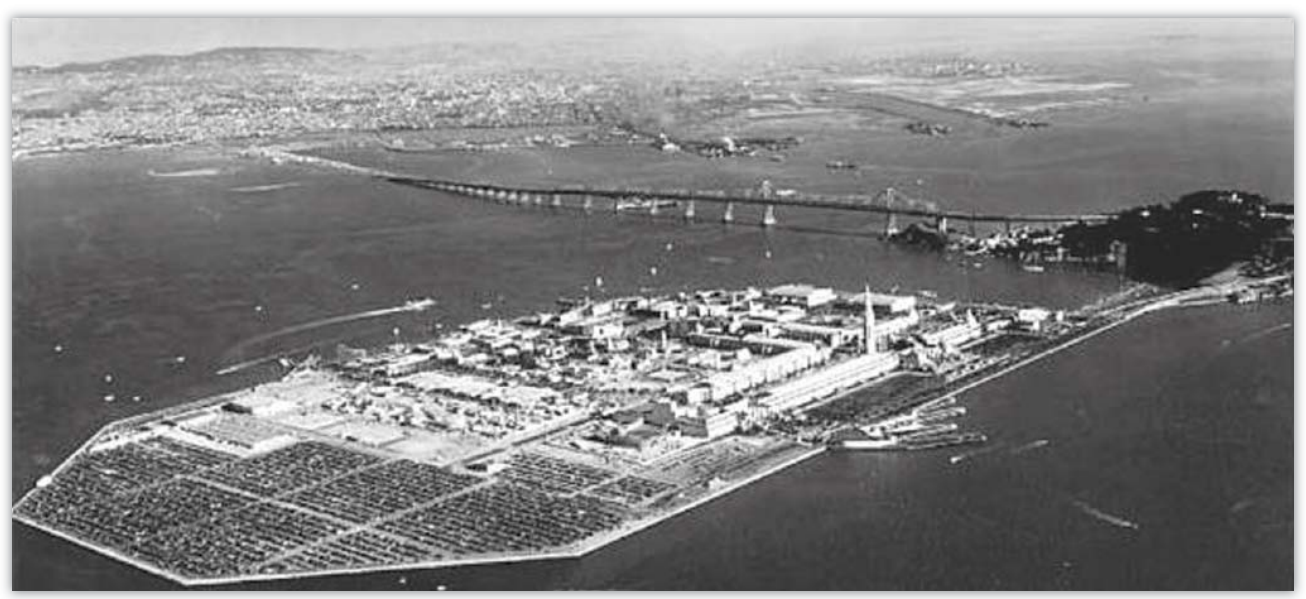
as Pan American Airways' seaplane terminal for its trans-Pacific Clipper service (below right), and the intention was that after the close of the Exposition in 1940, Treasure Island would become an international airport for San Francisco. However, in World War II the U.S. Navy took over the island, and San Francisco had to build its international airport elsewhere. (Photographs courtesy of the San Francisco Museum history collection.)

southwesternmost limit, the sand waves appear to merge with another field of sand waves that covers the northeast flank of Harding Rock (fig. 2). Much of the surface of Point Knox Shoal is covered by small sand waves less than 3 feet $(1 \mathrm{~m})$ in height and of variable orientation. The southwesternmost part of the shoal is characterized by a zone of irregular to linear depressions with intervening highs. The USGS multibeam sonar image of this part of the shoal yields an impression of intense disruption and a chaotic fabric (fig. 2). The area on Point Knox Shoal typified by this chaotic fabric covers 0.35 square mile $\left(0.9 \mathrm{~km}^{2}\right)$. The part of the shoal between this chaotic zone and Points Stuart and Knox on Angel Island is topographically lower than the surrounding shoal (fig. 2). This topographic depression covers 0.3 square mile $\left(0.8 \mathrm{~km}^{2}\right)$ and trends northeast-southwest. It is separated from the deeper Raccoon Strait by a submerged sediment ridge. Much of the floor of the depression occurs under 50 to 60 feet (15-18 m) of water.

Bathymetric maps from the 1800's and early 1900's are not sufficiently detailed to show whether the disrupted zone and the topographic depression existed on Point Knox Shoal in those times. However, there is reason to believe that these areas on Point Knox Shoal have been greatly modified by more recent dredging activities.

\section{Origin of the Topographic Depression on Point Knox Shoal}

Day (1938), Scheffauer (1954), and Cruickshank and Hess (1975) document that the area southwest of Angel Island, including much of Point Knox Shoal, was used as a borrow

pit and sand-mining area during 1936-1938 for construction fill (fig. 10). This fill material was used to create Treasure Island on a shoal northwest of Yerba Buena Island for the 1939 Golden Gate International Exposition (fig. 11). There is no record of the specific volume of material excavated from Point Knox Shoal, nor of the exact sites from which it was removed on the shoal. However, Scheffauer (1954) reported 20 to 29 million cubic yards (15.3-22.2 million $\mathrm{m}^{3}$ ) as the total volume removed from both Point Knox Shoal and Alcatraz/Presidio Shoal to create Treasure Island. Hopper dredges were the common equipment used to excavate the sand for construction fill (Scheffauer, 1954; Cruickshank and Hess, 1975). A hopper dredge deploys a dragarm over the side of a barge and uses suction to extract sand from the sea floor. The dragarm and its draghead are only capable of skimming the sea-floor surface and provide minimal penetration (less than 3 feet or $1 \mathrm{~m}$ ).

A plot of the location of the 1939 Golden Gate International Exposition dredging site on Point Knox Shoal projected onto USGS multibeam imagery reveals that most of the topographic depression on Point Knox Shoal coincides with the westernmost portion of the 1936-1938 dredging site (fig. 10). The volume of material removed from the topographic depression on Point Knox Shoal was estimated by geometrically draping a flat surface over the depression. The resulting estimate of 3.1 million cubic yards $\left(2.4\right.$ million $\left.\mathrm{m}^{3}\right)$ is a reasonable minimum figure considering the estimates cited by 
Scheffauer (1954) for the total volume of sediment removed from both Point Knox and Alcatraz/Presidio Shoals.

The depression in Point Knox Shoal appears to be too deep and extensive to have been dredged solely by hopper dredges, which at each pass typically can excavate an elongate depression only 3 to 6 feet (1-2 m) wide and less than 3 feet (1 m) deep. A dredge with the capacity to excavate more deeply into the substrate was probably used on Point Knox Shoal in addition to or subsequent to the 1936-1938 dredging by hopper dredges. For example, a stationary dredge is capable of excavating the substrate to a depth of at least 30 to 50 feet (10$15 \mathrm{~m}$ ) (deGroot, 1979). The topographic depression in Point Knox Shoal is similar to a borrow area in South San Francisco Bay adjacent to Bay Farm and Alameda Islands (fig. 12). This borrow area encompassed roughly 50 million square feet (4.7 million $\mathrm{m}^{2}$ ) and served as a source of sediment for construction fill on Bay Farm Island. It likely was excavated by a stationary dredge, and in places was 26 to 33 feet $(8-10 \mathrm{~m})$ deeper than the surrounding bay floor (National Ocean Survey chart no.18650, 1980 edition).

The Point Knox Shoal topographic depression occurs within the boundaries of an active sand mining lease area designated "PRC-709.1 North" by the California State Lands Commission (CSLC). The USGS multibeam imagery from 1997 (fig. 2) revealed that the floor of the depression is covered by small natural sand waves, 0.3 to 3 feet $(0.1-1 \mathrm{~m})$ in height, with a diverse mix of orientations. No apparent signs of recent dredging were seen within the topographic depression.

There may have been a depression on Point Knox Shoal even before dredging occurred there. The depression occurs offshore of two prominent topographic features, Points Knox and Stuart on Angel Island (fig. 2). Natural topographic depressions occur offshore of Points Blunt and Campbell on Angel Island and offshore of the Belvedere Peninsula (fig. 2). A disposal site southwest of Alcatraz Island used for materials dredged from shipping channels in the bay (fig. 2) was, in the 1800's, a topo-
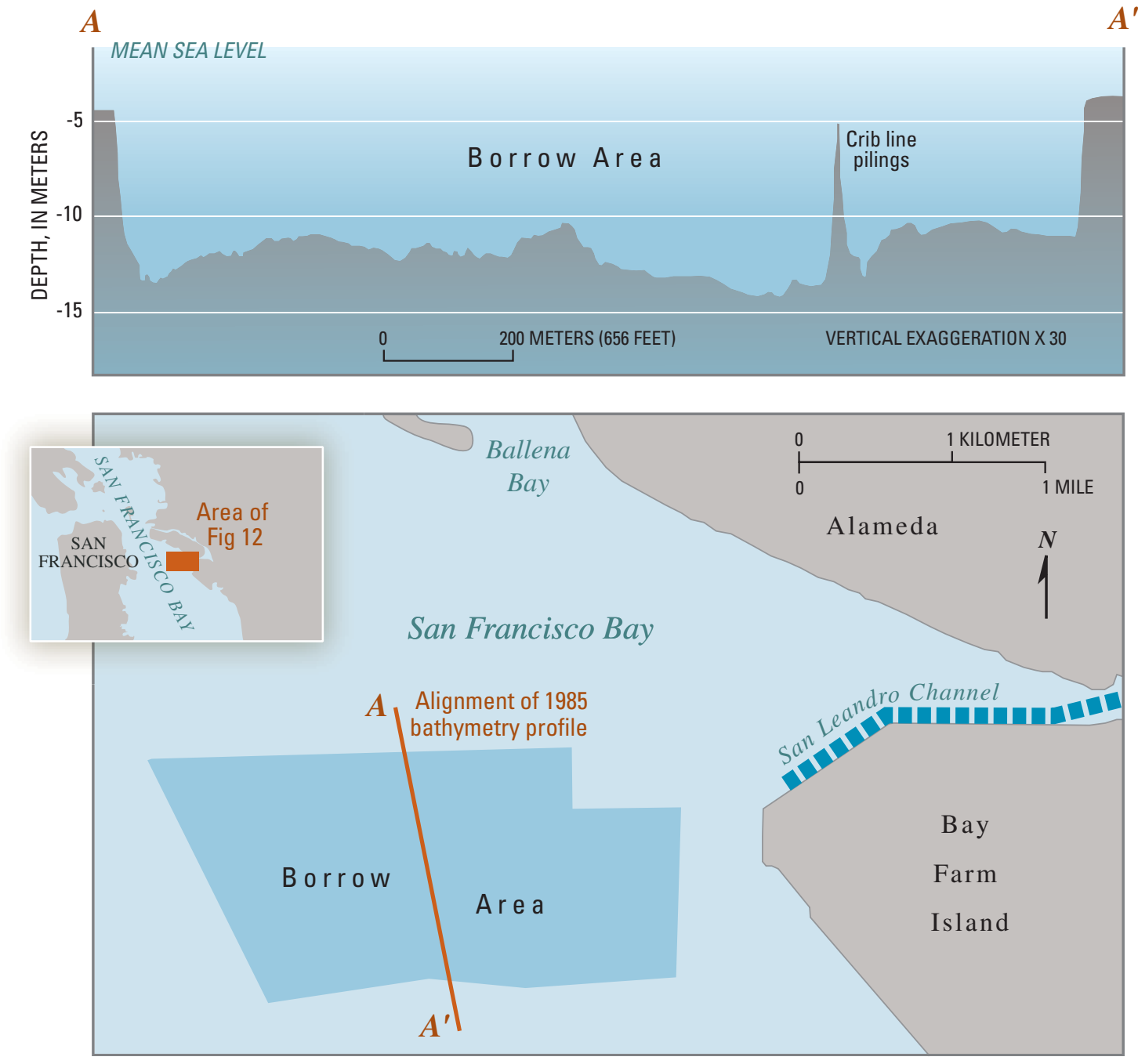

Figure 12. Bathymetric profile and map of borrow area set aside for dredging of fill material in San Francisco Bay adjacent to Bay Farm and Alameda Islands. This borrow area encompassed roughly 5.6 million square yards $\left(4.7\right.$ million $\left.\mathrm{m}^{2}\right)$ and served as a source of sediment for construction fill on Bay Farm Island. It likely was excavated by a stationary dredge and in places was 26 to 33 feet $(8-10$ $\mathrm{m})$ deeper than the surrounding area. (U.S. Geological Survey data collected in 1985 using 200-kHz sonar.) 
graphic depression 165 feet $(50 \mathrm{~m})$ below the adjacent bay floor (U. S. Environmental Protection Agency, 1996). In central San Francisco Bay there appears to be a clear correlation between submerged topographic depressions and prominent adjacent onshore topographic features such as points, headlands, and islands. Once a depression is formed in the bay floor, tidal currents appear to maintain that topographic feature as a depression by inhibiting sedimentation or by causing erosion.

\section{The Disrupted Zone on Point Knox Shoal}

The appearance of the southwestern part of Point Knox Shoal is distinct from any other part of the floor of west-central San Francisco Bay imaged by the USGS in 1997 (fig. 2; Chin and others, 1997, 1998). A thoroughly chaotic and intensively disturbed fabric characterizes this part of the shoal, in contrast to the relatively smooth fabric of the adjacent topographic depression. This disturbed zone is at a water depth of 52 to 78 feet (16-24 m). On 100-kHz sidescan-sonar images, the chaotic fabric is a composite of closely spaced circular, semicircular, and elongate depressions with intervening higher areas (fig. 13). These depressions and their intervening highs are so numerous over a relatively small area that they appear to interlace.

The circular to semicircular depressions range in size from 6 to 26 feet (2-8 m) wide and from 6 to 65 feet (2-20 $\mathrm{m})$ long and occur both individually and in clusters (fig. 13). Many of these depressions are characterized by a raised rim 3 to 6 feet (1-2 m) high, typically on one side only.

Elongate depressions (or troughs), from linear to curvilinear in shape, appear to be more numerous than the circular depressions within the disrupted zone on Point Knox Shoal. These troughs are commonly 6 to 33 feet $(2-10 \mathrm{~m})$ wide, 33 to 200 feet (10-60 m) long, and 3 to 10 feet (1-3 m) deep as measured using 100-kHz sidescan sonar (fig. 13). The troughs, like the circular depressions, also commonly feature a flanking rim that parallels one side and rises 3 to 6 feet (1-2 m) above

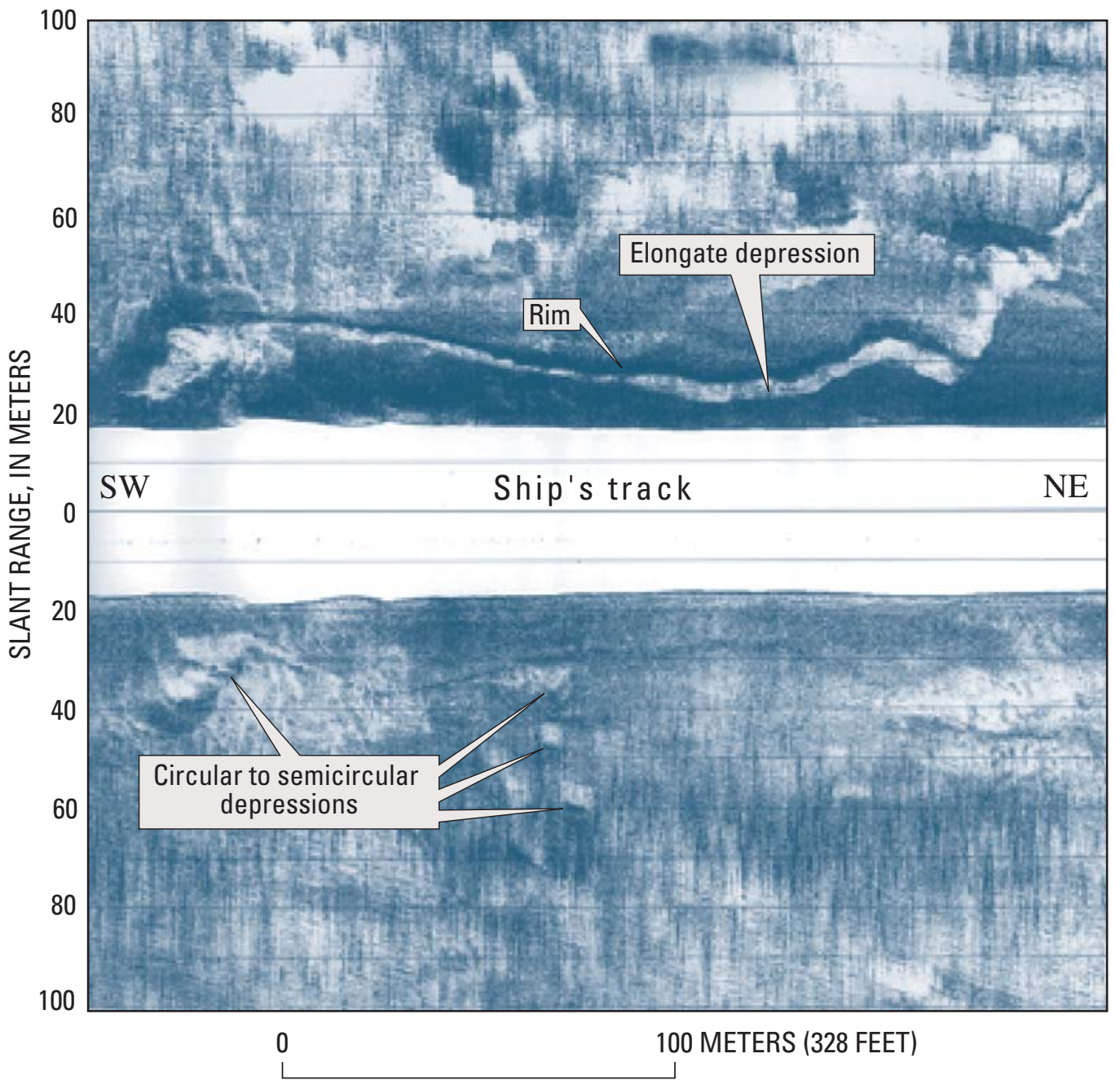

Figure 13. U.S. Geological Survey sidescan-sonar image (100 kHz; uncorrected) collected in January 1998 showing dredge-related features in the disturbed zone on Point Knox Shoal. Features visible in this image include elongate troughs (depressions), rims, and circular to semicircular depressions. Compare this to figure 15. (For explanations of slant-range scale and light and dark areas in image, see figure 8.) 
the flank of the trough. Troughs may occur adjacent to or distinct from circular depressions. On sidescan-sonar images (both 95 and $100 \mathrm{kHz}$ ), troughs appear to cross one another, sometimes several times.

Previous surveys by Rubin and McCulloch (1979) and Chin and Clifton (1990) of central San Francisco Bay, based largely on nonoverlapping reconnaissance-style sidescan-sonar coverage $(100 \mathrm{kHz})$, did not reveal any extensive zones of bay floor with chaotic or disrupted fabric. However, analysis of original sidescan-sonar images from the Rubin and McCulloch (1979) survey showed that similar circular to semicircular and elongate depressions did exist in the same area on Point Knox Shoal. The number and density of depressions appear to have been much less than in the 1997 survey, possibly because of the fewer number of transects available. The only area of bay floor remotely similar to this disrupted zone occurs on Presidio Shoal, just north of the San Francisco waterfront, and is discussed below.

Several lines of evidence indicate that the disrupted zone on Point Knox Shoal is largely due to dredging. Furthermore, in contrast to the topographic depression on the shoal, probably created by decades-old dredging, the disrupted zone is thought to be the result of more recent dredging activities. The disrupted zone largely occurs outside of the 1936-1938 borrow area (fig. 10).

Today, sand-and-gravel aggregate mining companies that hold leases granted by CSLC are allowed to extract sand from the bay floor. The leases are monitored by CSLC, San Francisco Bay Conservation and Development Commission (BCDC), and USACE, the regulatory agencies responsible for overseeing present-day sand mining on submerged State lands. A map of current lease areas provided by CSLC (fig. 14) shows that lease areas PRC 709.1 North and PRC 2036 include the disrupted zone of Point Knox Shoal. Lease area PRC 7779 is adjacent to PRC 2036 and extends to the southwest; this lease area includes the periphery of Point Knox Shoal (fig. 14).

During the January 1999 USGS cruise in west-central San Francisco Bay, hopper dredges were observed over a 2-day period mining sand on Alcatraz, Presidio, and Point Knox Shoals. The positions of the sand-mining dredges were fixed using DGPS. Later, after the dredges left the area, the USGS ran 100-kHz sidescan-sonar transects on Point Knox Shoal to examine bed features caused by the dredging. Figure 15 shows features on the shoal probably created by the dredging - circular to semicircular and elongate depressions, all of them unfilled and clearly recent in origin.

Bed features within the heart of the disrupted zone on Point Knox Shoal are so numerous, closely spaced, and interwoven that it is hard to distinguish individual features. Therefore, similar features found around the periphery of the disrupted zone are the key to deciphering their origin. Figure 16 shows bed features on the disrupted zone periphery as seen on the USGS 1997 multibeam base map. Individual and distinct linear to curvilinear elongate depressions (troughs) are present, some intersecting and crossing each other. These bed features are clearly very similar to the features observed just after hopper dredges mined the bay floor in 1999 (fig. 15). Because of this, all the circular to semicircular and elongate depressions found in the disrupted zone are interpreted to be the result of hopper-dredge sand mining. The circular to semicircular depressions, sometimes observed in a curving progression, are probably caused by the hopper dredge's trailing suction-arm draghead encountering the bay floor discontinuously. In a number of sidescan-sonar examples, a succession of pits was observed that led into an elongate trough. According to Scheffauer (1954), once a hopper dredge operator has determined that sand being extracted is suitable, the dredge barge is slowly moved forward with the dragarm trailing behind it and the draghead in contact with the bottom. The elongate trough, therefore, probably represents bay floor where the dragarm was left on the bed continuously to extract sand.

Close examination of figure 16 reveals that there is a subtle north-south grain present within the disrupted zone on Point Knox Shoal. Further examination of areas and bay-floor types adjacent to the disrupted zone shows that sand waves (generally more than 3 feet- $1 \mathrm{~m}$-in height) on the southeast flank of Point Knox Shoal and also in other areas of west-central San Francisco Bay exhibit an approximate north-south orientation. The subtle northsouth grain observed in the disrupted zone may represent the remnants of former sand waves, similar to those on the southeast flank of Point Knox Shoal and on Alcatraz/ Presidio Shoal. If so, sand mining activities within the disrupted zone have been so intensive that the sand waves are mostly obliterated.

\section{Presidio Shoal}

Presidio Shoal is part of a submerged shoal complex, including Alcatraz Shoal, that extends southwest from Alcatraz Island toward the Golden Gate (fig. 2). The two shoals are contiguous, with Alcatraz Shoal to the northeast and Presidio Shoal to the southwest. Water depths range from 36 to 60 feet (11-18 m) over Alcatraz Shoal and from 50 to 75 feet (15-23 m) over Presidio Shoal. The surfaces of both shoals are covered by prominent sand waves (fig. 2). The sand waves are approximately 3 to 6 feet (1-2 m) in height and have wavelengths ranging from about 80 to 290 feet (25-90 $\mathrm{m})$. The orientation of the sand waves is mostly north-south, varying to northnortheast-southsouthwest. On the southern margin of Presidio Shoal, just north of the San Francisco waterfront, the large 3- to 6-foot (1-2 m) sand waves appear to fade, and the bay floor is typified by smaller sand waves (generally less than 3 feet- $1 \mathrm{~m}-$ high) and by circular depressions that occur singly and in clusters.

The Marina District of San Francisco, adjacent to the southern margin of Presidio Shoal (fig. 3), has undergone significant modifications since about the mid-1800's. Dow (1973) and Bonilla (1991) documented extensive filling and alteration 


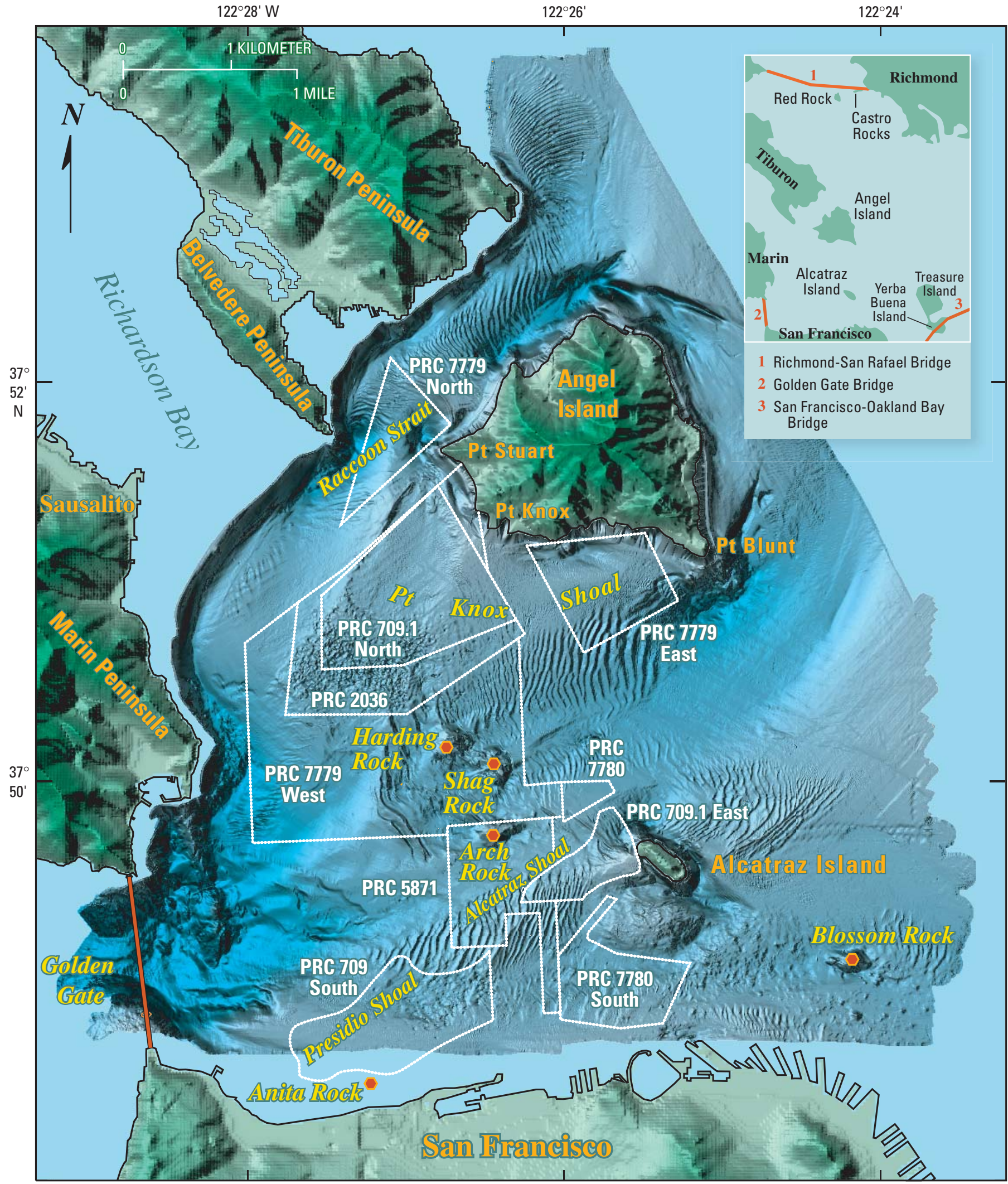

Figure 14. Approximate locations of lease areas for sand extraction in west-central San Francisco Bay as of June 1999, based on data from the California State Lands Commission (CSLC) Boundary Unit. Base map is composed of USGS shaded-relief images (see fig. 2). 
of this area. A shallow cove was located at the site of the present Marina District in 1851 (Bonilla, 1991). The greatest water depth within the cove was about 16 feet $(5 \mathrm{~m})$ MLLW. This cove existed until early 1912, when sediment was excavated from the southernmost edge of Presidio Shoal with suction dredges to create the fairgrounds for the 1915 Panama-Pacific Exposition (Bonilla, 1991). Markwart (1915) reports that from 1912 to 1915 approximately 1.3 to 2 million cubic yards (1-1.5 million $\mathrm{m}^{3}$ ) of sediment (70 percent sand, 30 percent mud) was excavated from Presidio Shoal for the exposition.

Presidio Shoal was also part of a designated borrow site (fig. 10) for the 1939 Golden Gate Exposition (Schef- fauer, 1954; Cruickschank and Hess, 1975; Hagwood, 1982). Hopper dredges were used to extract an indeterminate amount of sand from the shoal from 1936 to 1938.

At present, Presidio Shoal is part of an active sandmining lease, designated PRC-709 South (fig. 14) by the CSLC. Additionally, most of Alcatraz Shoal is covered by three active lease sites, PRC-5871, PRC-709.1 East, and PRC-7780 South (fig. 14).

Almost all of the circular, semicircular, and elongate depressions on Presidio Shoal occur within the boundaries of PRC-709 South. These features on the southern margin of Presidio Shoal are broadly similar to the features in

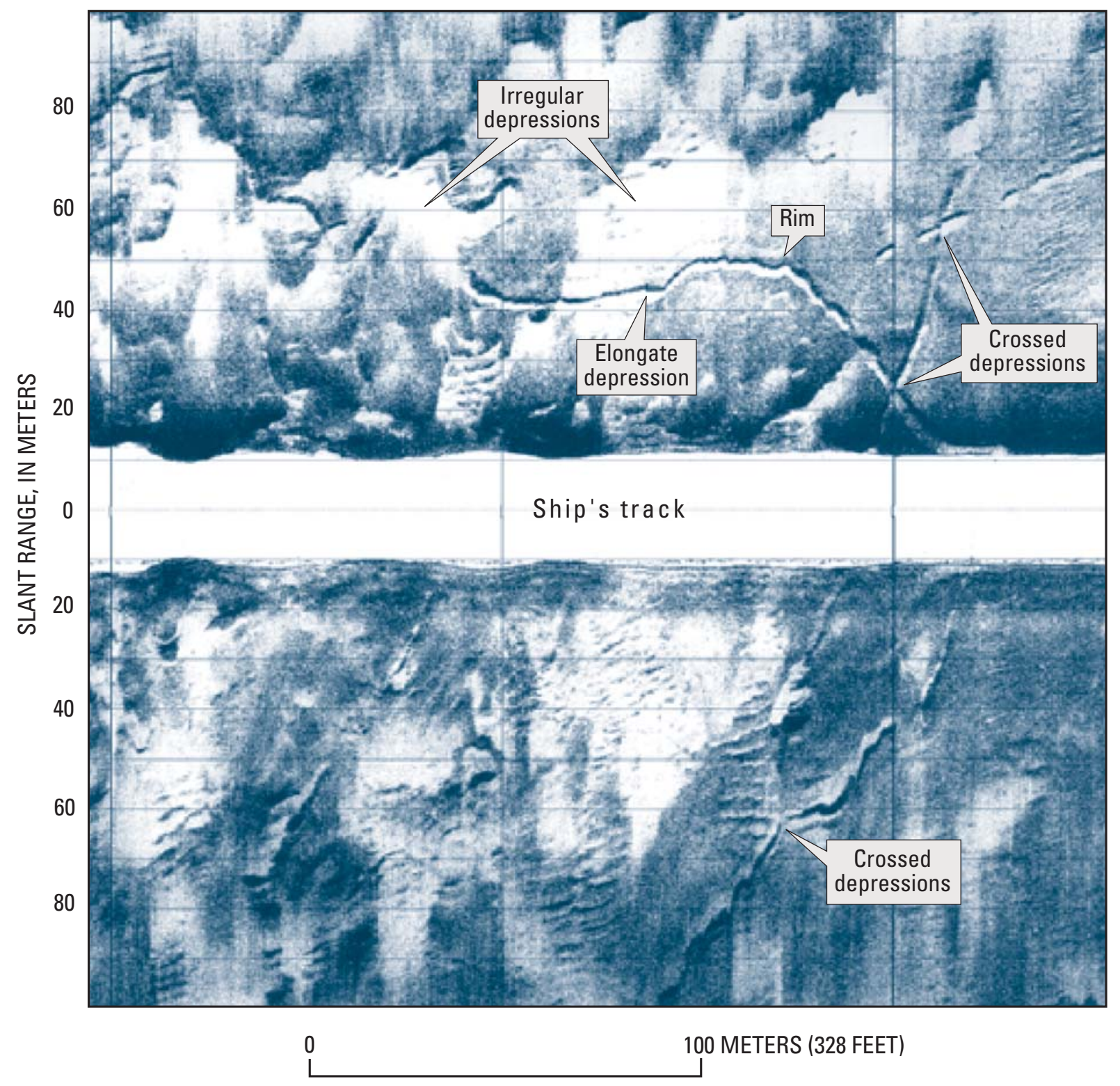

Figure 15. U.S. Geological Survey sidescan-sonar image (100 kHz; uncorrected) of recent dredge-related features on Point Knox Shoal collected in January 1999, shortly after a hopper dredge was observed operating over this part of the shoal. Note that elongate depressions cross each other several times. Compare this figure to figure 13. (For explanations of slant-range scale and light and dark areas in image, see figure 8.) 
the disrupted zone on the southwestern tip of Point Knox Shoal. Both sets of bottom features occur within present day sand-mining lease sites, and hopper dredges were observed mining sediment at each site during field surveys by USGS scientists in January 1999. After observing sand mining on Presidio Shoal, the USGS conducted a 100$\mathrm{kHz}$ sidescan-sonar survey of the dredge site. The features imaged were fresh and similar to those acquired on Point Knox Shoal after the passage of a sand-mining dredge. Circular and semicircular depressions on the images were 6 to 13 feet $(2-4 \mathrm{~m})$ in width, and elongate depressions were about 6 feet $(2 \mathrm{~m})$ in width and 65 to 250 feet $(20-75 \mathrm{~m})$ in length (fig. 17). As was also observed on Point Knox Shoal, both circular and elongate depressions have a flanking rim raised above one edge, and a number of elongate depressions cross each other. These manmade bottom features clearly cut across natural sand waves (fig. 17). The elongate depressions observed on 100-kHz sidescan-sonar images on Presidio Shoal after sand mining in 1999 were not evident on USGS 95-kHz multibeam imagery from 1997. They may have been below the resolution of the multibeam system, or absent at the time of the 1997 survey. No sand-mining dredges were observed on west-central San Francisco Bay during the 1997 survey.
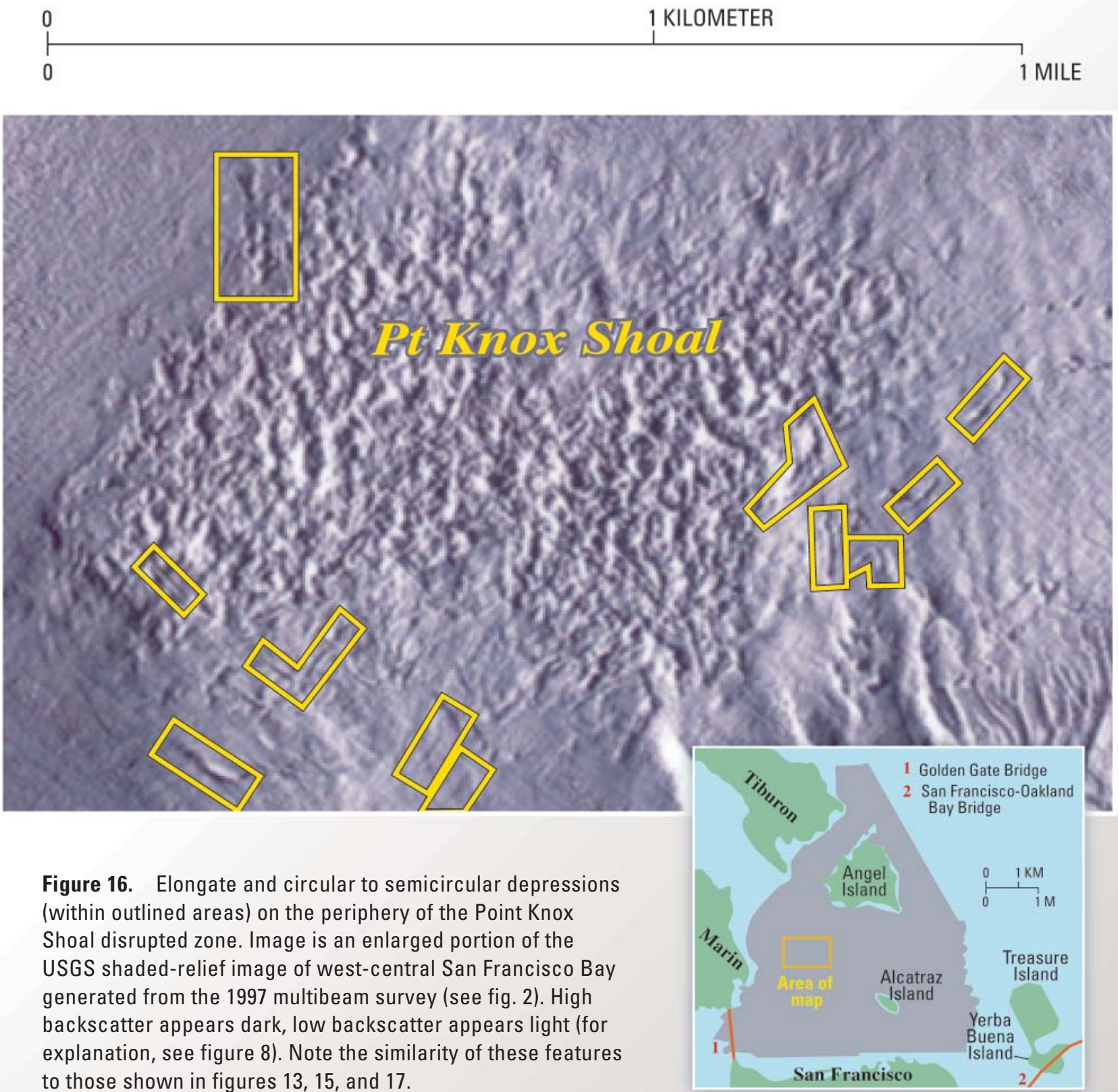


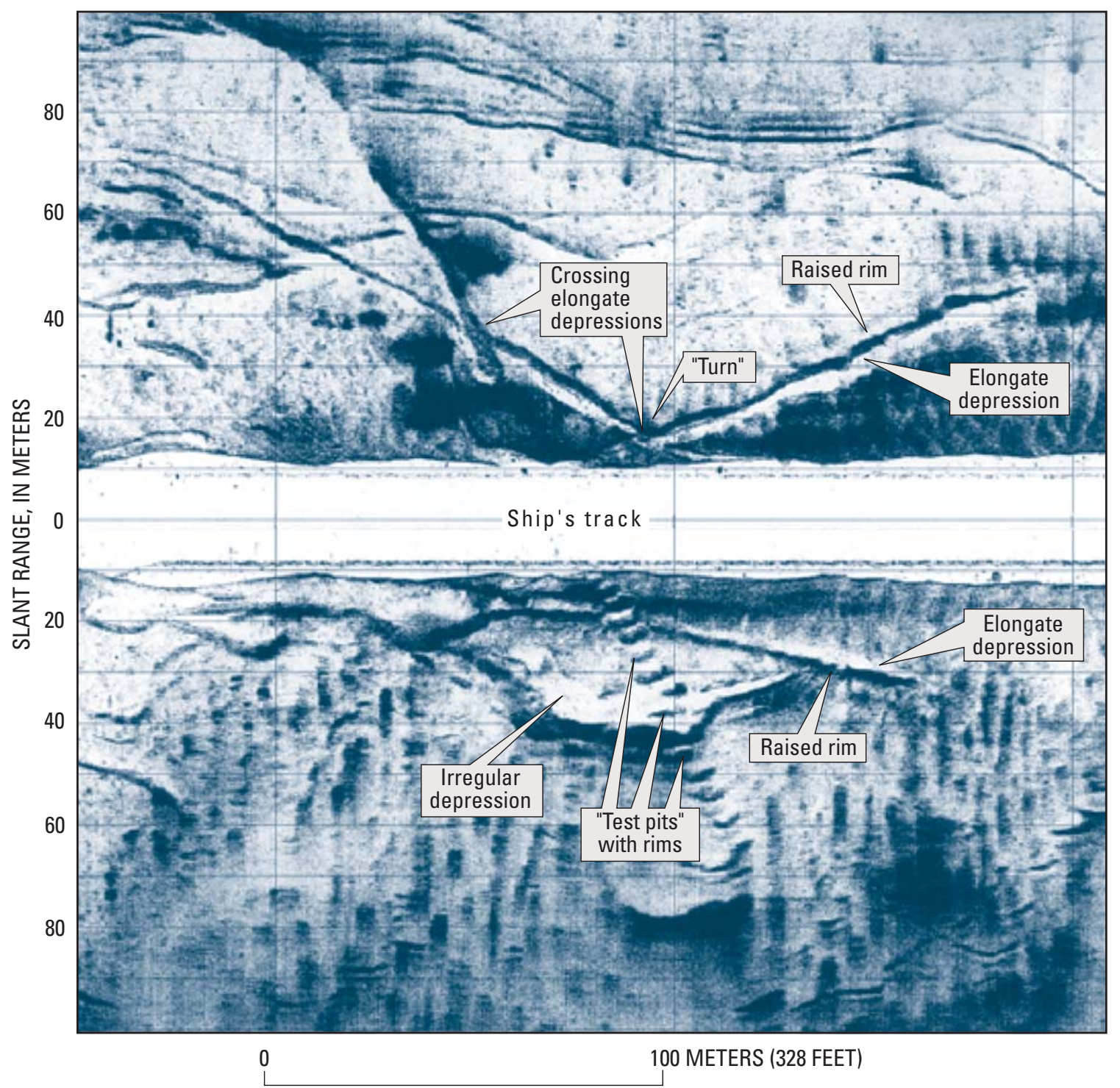

Figure 17. U.S. Geological Survey sidescan-sonar image (100 kHz; uncorrected) of recent dredge-related features on Presidio Shoal collected in January 1999, shortly after a hopper dredge was observed operating over this part of the shoal. The dredge-related features cut across natural sand waves (the light and dark stripes in the lower part of the image), and some of the elongate depressions cross over each other several times. Note the similarity of these dredged features to those in figures 13,15 , and 16. (For explanations of slant-range scale and light and dark areas in image, see figure 8.)

\section{Bedrock Knobs}

In January 1999, the USGS collected underwater video over Harding, Arch, and Shag Rocks to verify interpretations made from sidescan sonar (J.L. Chin and P.R. Carlson, unpub. data, 2000). As shown on the sonar images, the top of Shag Rock is strewn with rocky rubble and debris of all sizes and shapes (fig. 18). The size of rubble ranges from cobbles to large boulders several meters across. A large amount of the rock debris is angu- lar. Some rock appears to be in place, but mostly the underwater video showed blocky rubble scattered over the surface of Shag Rock. Similarly, the surfaces of Harding Rock and Arch Rock are strewn with rocky debris of all shapes and sizes from cobbles to boulders. Such debris is consistent with what would be expected for rock masses that had been blasted. A fair amount of rubble from blasting was evidently left in place on the rock knobs.

Available records indicate that the tops of these rock knobs in west-central San Francisco Bay have not been 


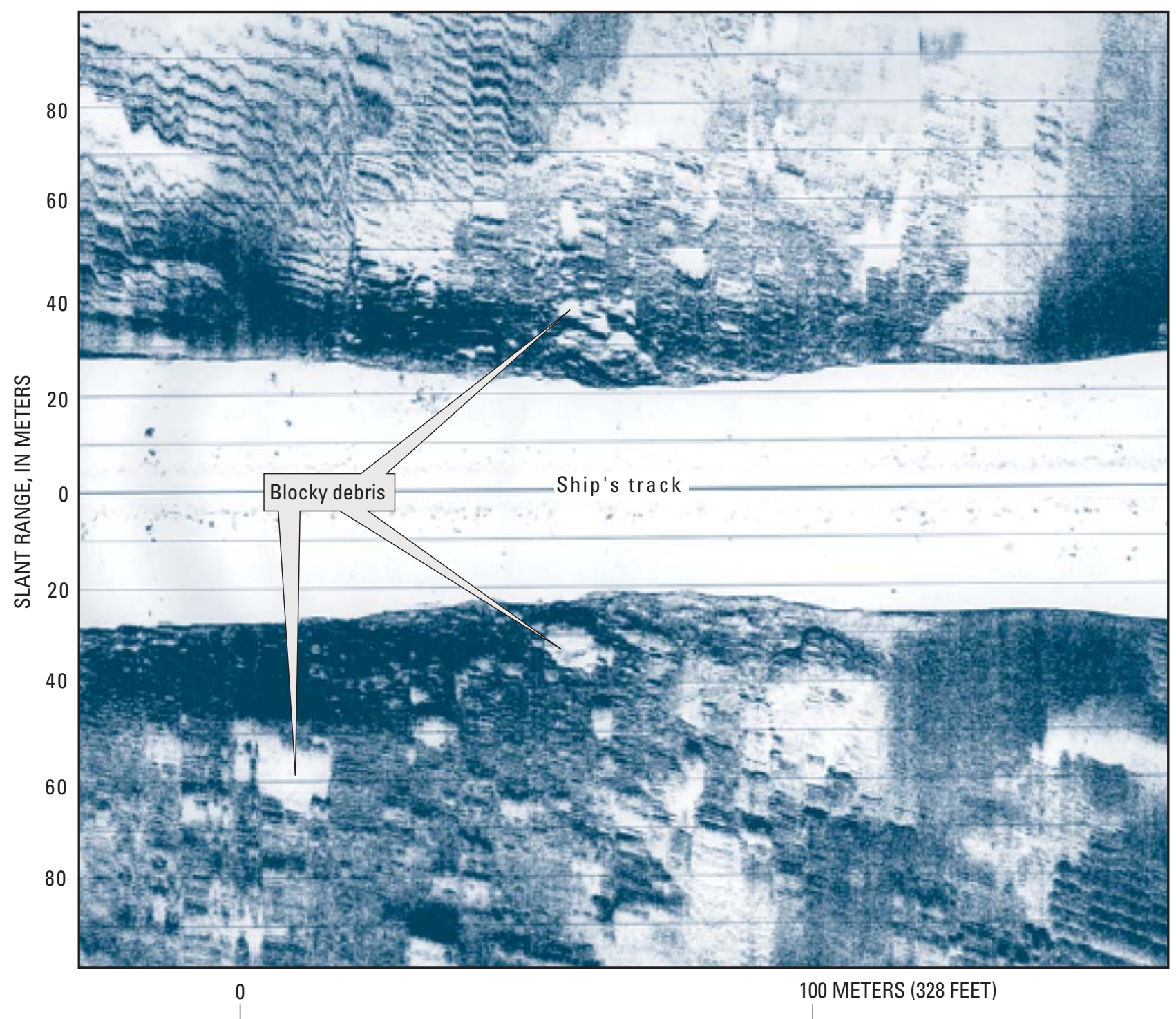

Figure 18. U.S. Geological Survey sidescan-sonar image (100 kHz; uncorrected) over Shag Rock collected in January 1999, showing the rocky debris that covers its surface. The debris includes boulders and blocky rubble of various sizes and shapes. On upper left side of figure are sand waves that terminate against the flank of Shag Rock. (For explanations of slant-range scale and light and dark areas in image, see figure 8.)

lowered artificially since the mid-1930's. Their present depths below the water surface are therefore suited to vessels with drafts typical of the first half of the twentieth century, making them a navigational hazard to the modern deep-draft vessels that now transit through west-central San Francisco Bay (fig. 19). Another factor that makes these rock knobs a potential hazard to safe navigation is that the navigation traffic lanes that vessels take into and out of San Francisco Bay have changed since the knobs were last lowered. At present, Hard- ing, Shag, and Arch Rocks lie within the westbound vesseltraffic lane (fig. 20). Blossom Rock (as well as the Alcatraz Disposal Site) is within the eastbound vessel-traffic lane. In addition, Harding Rock is within about 1,000 feet (300 m) of the two-way deep-draft vessel traffic lane (fig. 20).

Ports immediately adjacent to west-central bay include the Port of San Francisco, the Port of Richmond, and the Port of Oakland. Vessels that use the Port of Oakland are dominantly container vessels (fig. 21), whereas those using the Port of 


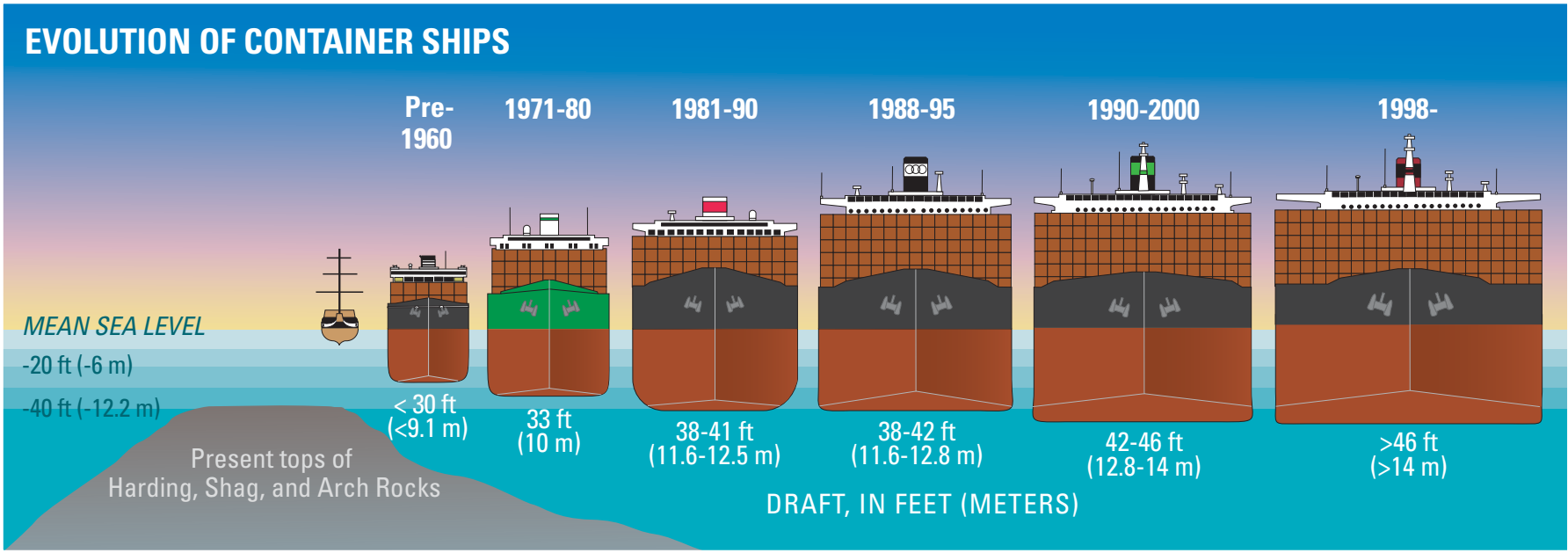

Figure 19. The evolution of vessel draft through time. Image at far left represents a sailing ship from the Gold Rush era; the other images show successive generations of ever-larger container ships. The evolution of oil tankers has paralleled that of container vessels, with increasing vessel size and draft over time. The bedrock knobs in San Francisco Bay that were artificially lowered to about 40 feet below mean sea level in the first half of the 20th century are clearly once again a potential hazard to the largest vessel (see fig. 20). Diagram modified from Pisani (1989); original schematic copyright by Port of Oakland, September 1989.

Richmond are oil tankers (fig. 22). An assortment of vessels, including passenger liners, call at the Port of San Francisco (San Francisco Bay Conservation and Development Commission and Oakland Metropolitan Transportation Commission, 1996). At the time the bedrock knobs were last lowered in the mid-1930's, the deepest draft vessels were steamships with 23-foot $(7 \mathrm{~m})$ drafts which required that the tops of the bedrock knobs be approximately 26 feet (8 m) MLLW. However, modern deeper draft vessels are now rapidly replacing smaller older vessels (fig. 19). The latest generation of container vessels are as much as 1,300 feet (396 m) long, 150 feet ( $46 \mathrm{~m}$ ) wide, and have drafts of 46 to 50 feet $(14-15 \mathrm{~m})$. These container vessels often carry as many as 5,000 "twenty-foot equivalent unit" (TEU) containers (San Francisco Bay Conservation and Development Commission and Oakland Metropolitan Transportation Commission, 1996). Larger, deeper draft vessels are more efficient and thus more cost effective, both to their owners and to ports. This trend toward larger, more cost-effective vessels is true not only for container vessels but also for oil tankers and passenger liners - transporting oil in a 50,000-ton tanker costs twice as much as in a 300,000-ton tanker over a 25,000-mile transit (Herbich, 2000).

Between 1988 and 1993 the annual number of ships visiting San Francisco Bay actually decreased by almost 300, while the volume of cargo coming into the bay increased. This trend is likely to continue as fewer but larger cargo and passenger vessels call in the bay. It is forecast that maritime cargo transiting San Francisco Bay will more than triple by the year 2020 (San Francisco Bay Conservation and Development Commission and Oakland Metropolitan Transportation Commission, 1996).

After the U.S. Congress proposed lowering the tops of the bedrock knobs in west-central San Francisco Bay to remove the potential hazard to navigation for deep-draft vessels (Carlson and others, 2000), the U.S. Army Corps of Engineers undertook a feasibility study in 2000. Earlier cost estimates for such a project ranged from 10 to 43 million dollars (Rogers, 1996), but in their recent feasibility study, USACE estimated the costs at more than $\$ 200$ million. USACE concluded that the benefits of lowering the bedrock knobs would not offset these high costs, because current navigation practices make an oil spill resulting from a tanker or other vessel grounding on one of the knobs very unlikely (U.S. Army Corps of Engineers, 2003). However, it is worth noting that the economic losses from the 1989 T/V Exxon Valdez oil spill in Prince William Sound, Alaska, are at least $\$ 2.8$ billion (State of Alaska, unpub. information accessed online on March 11, 2004, at http://www.evostc.state.ak.us/facts/economic.html). In addition, USACE was not asked in their recent study to consider the possible effects of spills of other kinds of toxic materials resulting from vessel groundings on the knobs.

Both environmentally and economically there is much at stake for the San Francisco Bay region. The Port of Oakland is the fourth largest port for containerized shipping in the United States and the third largest container port on the U.S. West Coast. San Francisco Bay is one of the three primary Pacific coast gateways for U.S. containerized cargoes; the others are San Pedro Bay and Puget Sound. At present 98 percent of the containerized goods arriving in the San Francisco Bay region, the nation's fourth largest metropolitan area, is discharged at the Port of Oakland. Additionally, California is the Nation's leading agricultural state, and many California agricultural products are exported through the Port of Oakland. The Port of Oakland currently has $\$ 700$ million in maritime projects under construction or in planning (Port of Oakland, Facts and Figures, unpub. data accessed online November 29, 2000 at http://www.portofoakland.com/maritime/index.html). The port was directly responsible for 9,600 jobs in 2000 ; this figure 


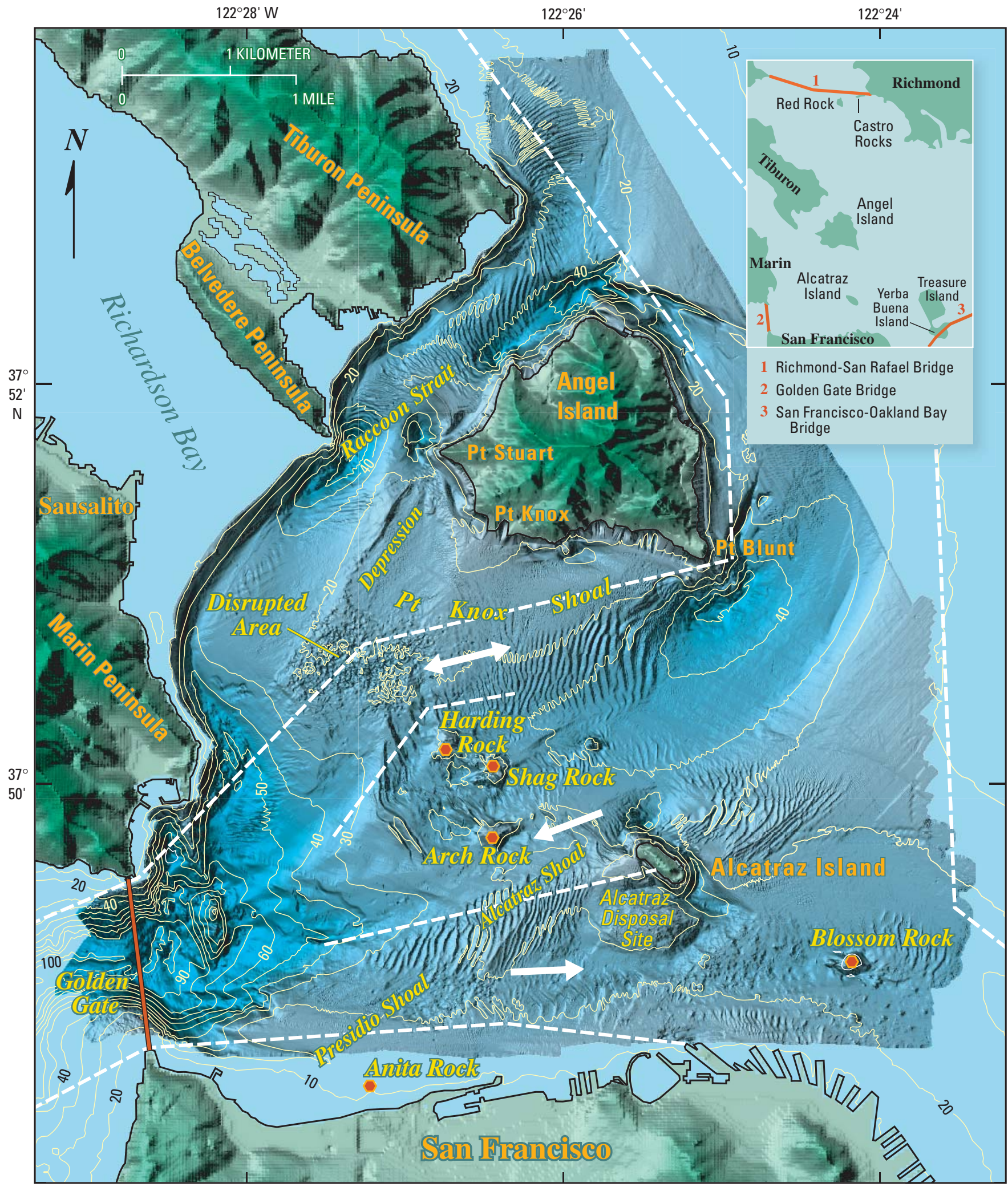

Figure 20. Traffic lanes for large vessels (1,600 gross tons or greater) in west-central San Francisco Bay, as designated by the U.S. Coast Guard's Vessel Traffic Service San Francisco (more information at http://www.uscg.mil/D11/vtssf). Lane boundaries are shown by dashed white lines, and white arrows indicate directions of vessel traffic. Two-way arrow marks the deep-water route for vessels of draft greater than 45 feet $(13.7 \mathrm{~m})$. Note that several of the bedrock knobs (red dots) are in the traffic lanes, and Harding Rock is even close to the deep-draft lane. Base map is composed of USGS shaded-relief images (see fig. 2). 

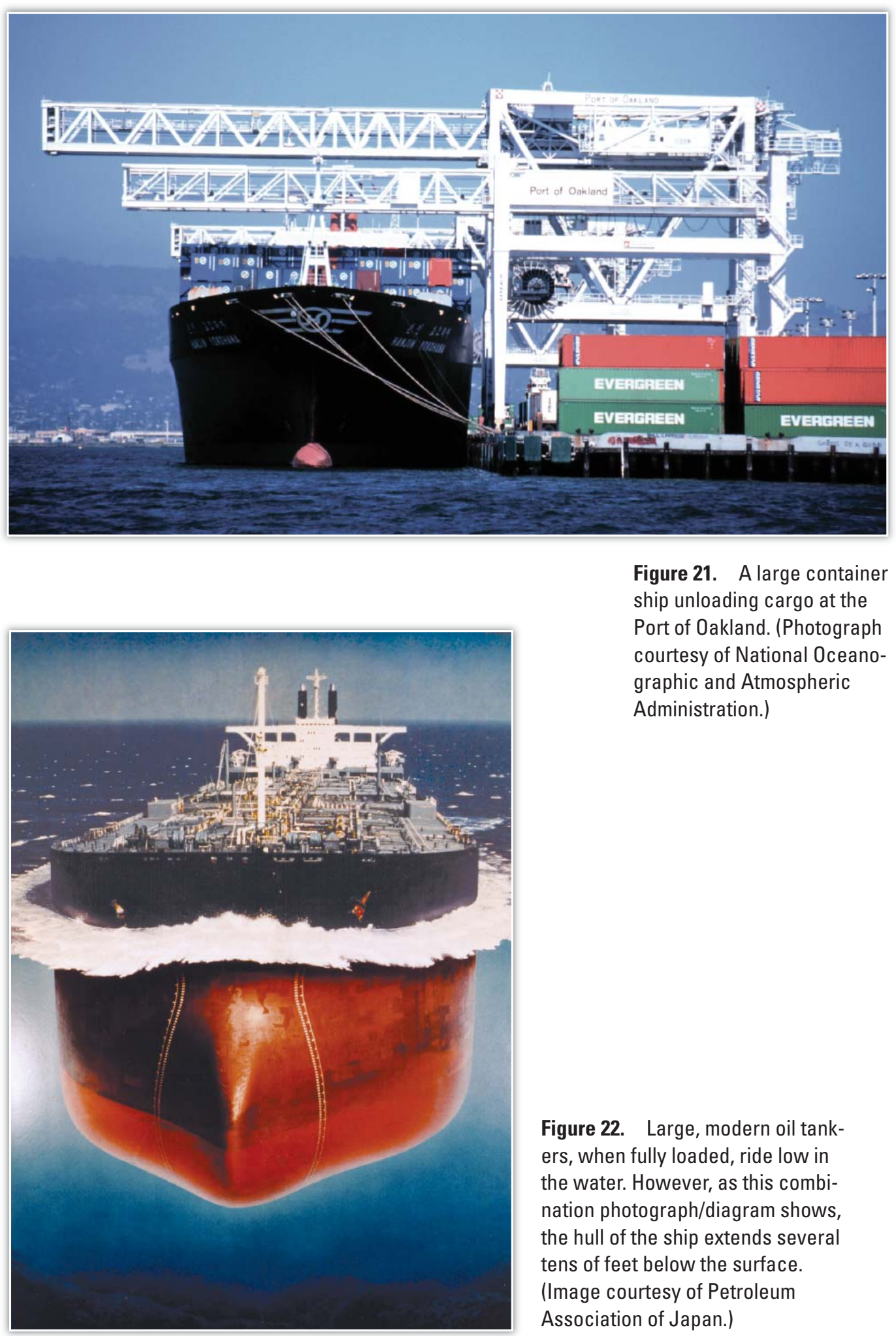

Figure 21. A large container ship unloading cargo at the Port of Oakland. (Photograph courtesy of National Oceanographic and Atmospheric Administration.)

Figure 22. Large, modern oil tankers, when fully loaded, ride low in the water. However, as this combination photograph/diagram shows, the hull of the ship extends several tens of feet below the surface. (Image courtesy of Petroleum Association of Japan.) 
is projected to increase to 14,000 by 2010 (Port of Oakland, Benefiting the California economy: unpub. data accessed online November 29, 2000, at http://www.portofoakland.com/ maritime/vision_07.html).

Tankers arriving at the Port of Richmond and the Port of Benicia together annually carry millions of gallons of crude oil that supplies refineries and ultimately consumers in the San Francisco Bay region. Although there have been no reported groundings of oil tankers on the bedrock knobs in the bay (Rogers, 1996), there have been other oil spills in San Francisco Bay that can be used to estimate the amount of potential damage that might be caused if a tanker struck one of these knobs. For example, an 8,000-gallon oil spill in October 1996 in San Francisco Bay cost approximately $\$ 10$ million to clean up. A much larger spill at the Martinez oil refinery in San Pablo Bay (north San Francisco Bay) in 1988 cost \$14 million to remediate. Annually, 700 to 1,000 oil tankers of all sizes enter San Francisco Bay and transit through west-central bay on their way to anchorages and refineries and carry an average of 800 million barrels of oil per year (Nolte, 1997). Furthermore, deep-draft container vessels and other large vessels can carry thousands to tens of thousands of barrels of fuel oil, enough that any grounding on their part could create an environmental crisis.

\section{Alcatraz Disposal Site}

One of the most prominent features on the floor of west-central San Francisco Bay is a disposal site located just southwest of Alcatraz Island (figs. 20, 23). This disposal site, used for material dredged from shipping channels in the bay, is bounded by Alcatraz Island to the northeast and Alcatraz Shoal to the west. The disposal site covers an area of about 0.25 square mile $\left(0.64 \mathrm{~km}^{2}\right)$, larger than the exposed landmass of Alcatraz Island (fig. 20). Water depths over the site in 1997 ranged from 33 to 36 feet $(10-11 \mathrm{~m})$ at the shallowest to about 65 to 82 feet (20-25 m) (fig. 20).

The first dredged waterway in San Francisco Bay was created in 1868; San Francisco Bay has been dredged periodically ever since. The increased waterborne commerce associated with and following the Gold Rush accelerated the requirement for dredging in San Francisco Bay to ensure navigable waterways. Dredging one part of the bay and disposing of the dredged material in another, open-water part of the bay (the Alcatraz site in particular), was the accepted method of operation for many decades. Dredged materials were disposed of at the Alcatraz site beginning in 1894, although it was not designated an official dredge disposal site until 1972 (U.S. Environmental Protection Agency, 1996).

Before 1894, the bay floor at the location of the Alcatraz Disposal Site was a topographic depression (fig. 23) with a maximum depth of about 165 feet $(50 \mathrm{~m})$ MLLW (U.S. Environmental Protection Agency, 1996). This topographic depression was probably similar to the present depression south and southeast of Point Blunt off Angel Island (fig. 20).

The Alcatraz Disposal Site was originally chosen because it was deep and it was assumed that the strong tidal currents that flow through west-central San Francisco Bay would disperse dredged material from the site. A study in 1987 demonstrated that there was no significant change in sediment composition at the Alcatraz Disposal Site for 1 to 3 months after disposal of material, suggesting that material remained at the site for at least that long (U.S. Environmental Protection Agency, 1996).

By 1982, the mound of material at the Alcatraz Disposal Site had become a potential navigational hazard, rising to within about 36 feet $(11 \mathrm{~m})$ of the water surface (Long Term Management Strategy, 1995). In 1987, USACE began requiring all disposal materials to be slurried or broken up and regulated the type, volume, and frequency of disposal, helping to limit further growth of the mound (Long Term Management Strategy, 1995). Since 1989, both yearly and monthly limits on dredge material disposal have been in effect for the Alcatraz site. However, continued mounding of dredged materials has generated increased concern about the fate, erodibility, and dispersion of the material dumped at the site (Long Term Management Strategy, 1995).

Using the 1997 multibeam dataset and GIS tools, the USGS made projections of the past and present volume and nature of sediment at the Alcatraz Disposal Site to aid in assessing the scope of the mounding problem (fig. 23). This projection showed that, as of spring 1997, there were approximately 8.7 million cubic yards $\left(6.7\right.$ million $\left.\mathrm{m}^{3}\right)$ of sediment in the mound at the disposal site.

\section{Dredging Issues}

Two general types of dredging occur within west-central and adjacent parts of San Francisco Bay-(1) sand mining for construction aggregate and (2) maintenance and improvement dredging of harbors and navigation waterways. Maintenance dredging alleviates short-term problems, such as shoaling of harbors, waterways, or channels, but carries with it the problem of dredge material disposal. Dredging, no matter for what purpose, alters the environment of the bay floor. If the dredged area does not refill with native material of the same grain size and composition, the change can be permanent. If the bay floor does not fill back in or refills with different material, the biological habitat at the dredge site will be altered.

\section{Sand Mining in West-Central Bay}

Millions of cubic yards of sand and gravel have been permanently removed from bay-floor shoals since 1915 . The process continues today, as active sand-mining leases allow private contractors to extract sand and gravel from submerged State lands on a permit basis (fig. 14). At present no fewer than 10 sand-mining lease sites exist in west-central San Francisco Bay that are regulated by the California State Lands Commission (CSLC).

Sidescan-sonar and multibeam surveys of Point Knox Shoal in west-central bay in 1975 (Rubin and McCulloch, 1979) and 1997 (Chin and others, 1998) both show bay-floor 


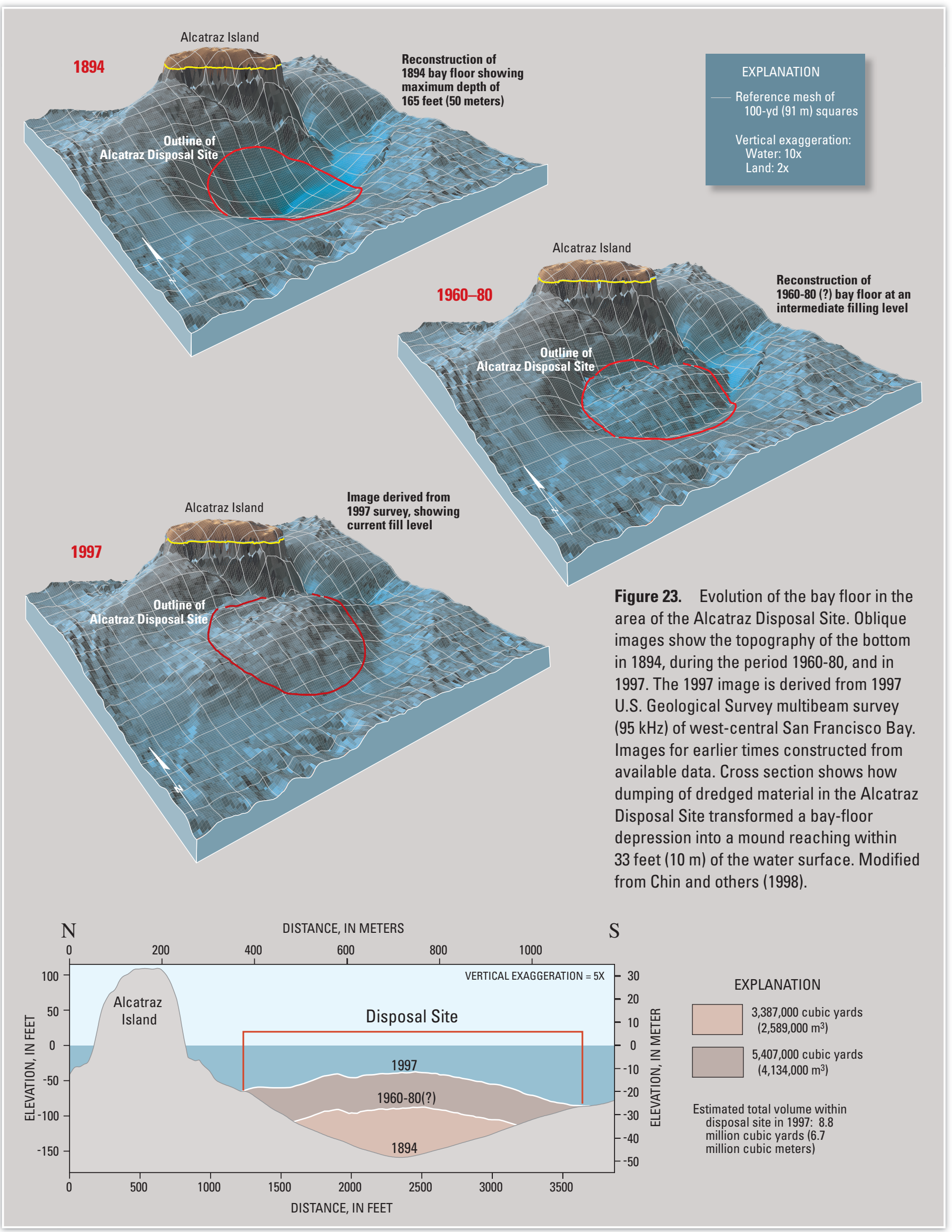


features attributable to sand mining. The physical alteration of the bay floor on Point Knox Shoal, as shown by the 1997 USGS multibeam survey (fig. 2), is significant. The dredgerelated features are so numerous as to literally obliterate the fabric of the bay floor (fig. 16). More recent dredging has further modified the bay floor on the shoal (fig. 15). It is not known how long the topographic depressions interpreted as dredge-related persist on the bay floor. It is also not known whether and how these depressions fill in after dredging.

The total volume of sand in the west-central bay shoals that are in active sand mining leases is unknown. Sand miners conduct yearly hydrographic surveys of their lease sites in the bay as required by permitting agencies. However, changes indicated by these surveys do not reveal what is happening in three dimensions on the shoals or their adjacent areas, nor do they yield an accurate inventory of sand resources. The volume of commercially extractable sand and gravel in these shoals needs to be known to prevent resource depletion. Additionally, it is not known whether the sand shoals in west-central bay are being naturally replenished, are in equilibrium, or are eroding. Natural sand replenishment could come from material flowing through the Sacramento-San Joaquin Delta and the north bay, from local sources such as eroding bedrock, or from sediment carried in from beyond the Golden Gate.

\section{Maintenance and Improvement Dredging}

Any discussion of maintenance and improvement dredging in west-central San Francisco Bay should be seen in a national and regional dredging perspective. The United States annually spends about $\$ 800$ million to dredge more than 400 million cubic yards $\left(300\right.$ million $\mathrm{m}^{3}$ ) of sediment from ports, harbors, and waterways (Patella, 2000). This amount of dredged material would cover a four-lane highway stretching from Los Angeles to New York City to a depth of 4 feet $(1.2 \mathrm{~m})$, or fill one million dump trucks (American Association of Port Authorities, Port Facts and Statistics: unpub. data accessed online November 29, 2000 at http://www.aapa-ports.org/portedu.html). The present and future trend for shipping in U.S. ports is for fewer but larger vessels. The draft of these larger vessels is critical to their economy of scale but affects each port's ability to accommodate them. A loss of 1 inch $(2.5 \mathrm{~cm})$ in draft for a vessel of 1,000foot $(305 \mathrm{~m})$ length can result in the loss of as much as 270 tons of cargo-carrying capacity (Patella, 2000).

Maintenance and improvement dredging has become increasingly important since the first Federal navigation channel was created in the 1800's. However, the dredging process has also come under greater scrutiny because of environmental concerns. For example, nationally, 3 to 5 percent of dredged material is contaminated and cannot be reused for beneficial purposes (Patella, 2000).

About 6 million cubic yards $\left(4.6\right.$ million $\left.\mathrm{m}^{3}\right)$ of sediment is dredged from San Francisco Bay each year (Goldbeck, 1999). This volume includes only maintenance dredging of existing waterways, not new projects, and volumes typically vary from year to year. The San Francisco Bar Channel, just outside the Golden Gate, is dredged to a maintenance depth of 56 feet $(17 \mathrm{~m})$ MLLW. The deep passage through the Golden
Gate itself is approximately 330 feet (101 m) MLLW and is naturally scoured by tidal currents. The tops of Harding, Shag, Arch, and Blossom Rocks in west-central bay are all in the range of 36 to 40 feet (11-12 m) MLLW. The Alcatraz Disposal Site's shoal depth varies, but the USGS multibeam survey in the spring of 1997 showed it to be 33 to 36 feet (10-11 m) MLLW. Water depth under other parts of the deepwater vessel-traffic lanes is about 53 feet $(16 \mathrm{~m})$ MLLW at the shallowest. Within 0.3 mile $(0.5 \mathrm{~km})$ northeast of Alcatraz Island the water depth shoals to about 40 to 46 feet (12-14 m) MLLW, although this area is not in the deep-water vessel traffic lane.

In the San Francisco Bay area, dredging and the disposal of dredged material are managed by a consortium of agencies, which have established the Long Term Management Strategy (LTMS) program. This group consists of the San Francisco Bay Conservation and Development Commission (BCDC), San Francisco Bay Regional Water Quality Control Board (RWQCB), State Water Resources Control Board (WRCB), U.S. Environmental Protection Agency (USEPA), and USACE. Local entities that have an interest in dredging and disposal also participate in the LTMS. The LTMS was established in 1991 to resolve controversies regarding dredged material disposal.

Before 1991, most dredged material from San Francisco Bay projects had been disposed of at the Alcatraz Disposal Site and other in-bay sites. However, by the mid-1980's, the Alcatraz mound had grown to the extent that it had become a navigational hazard, indicating that dredged material dumped there was not dispersing. Fishermen and environmentalists protested that the mud dumped at Alcatraz was harmful to marine life, and they blockaded the dumpsite in 1989 (Goldbeck, 1999). Years of "mudlock" resulted, when dredged material lacked a local site for disposal, and maintenance and improvement dredging had to be diminished until a solution was found. The disposal of dredged material is not a modern problem. As early as the late 1800's, USACE showed concern over the effects of the disposal of dredged material in San Francisco Bay (Hagwood, 1982).

The LTMS has alleviated "mudlock" in San Francisco Bay by getting all interested parties to work together for solutions. Using the results of USGS studies, USEPA designated the San Francisco Deep-Ocean Disposal Site (SFDODS) in 1994, 55 miles ( $88 \mathrm{~km}$ ) outside the Golden Gate in the Pacific Ocean in water depths of 8,200 to 9,800 feet (2,500-3,000 m) (Karl and others, 2001). LTMS has coordinated and streamlined the processing of permit applications for dredging and dredged-material disposal. LTMS has the mission of coordinating dredging and disposal for the San Francisco Bay area for 50 years from 1991.

The LTMS strategy will use as much dredged material as possible for wetland restoration and other beneficial reuse projects, but about 20 percent of dredged material will continue to be disposed of at sites in the bay, and the remainder will be taken to SFDODS. This strategy will be phased in over a decade (Goldbeck, 1999). The long-term success of 


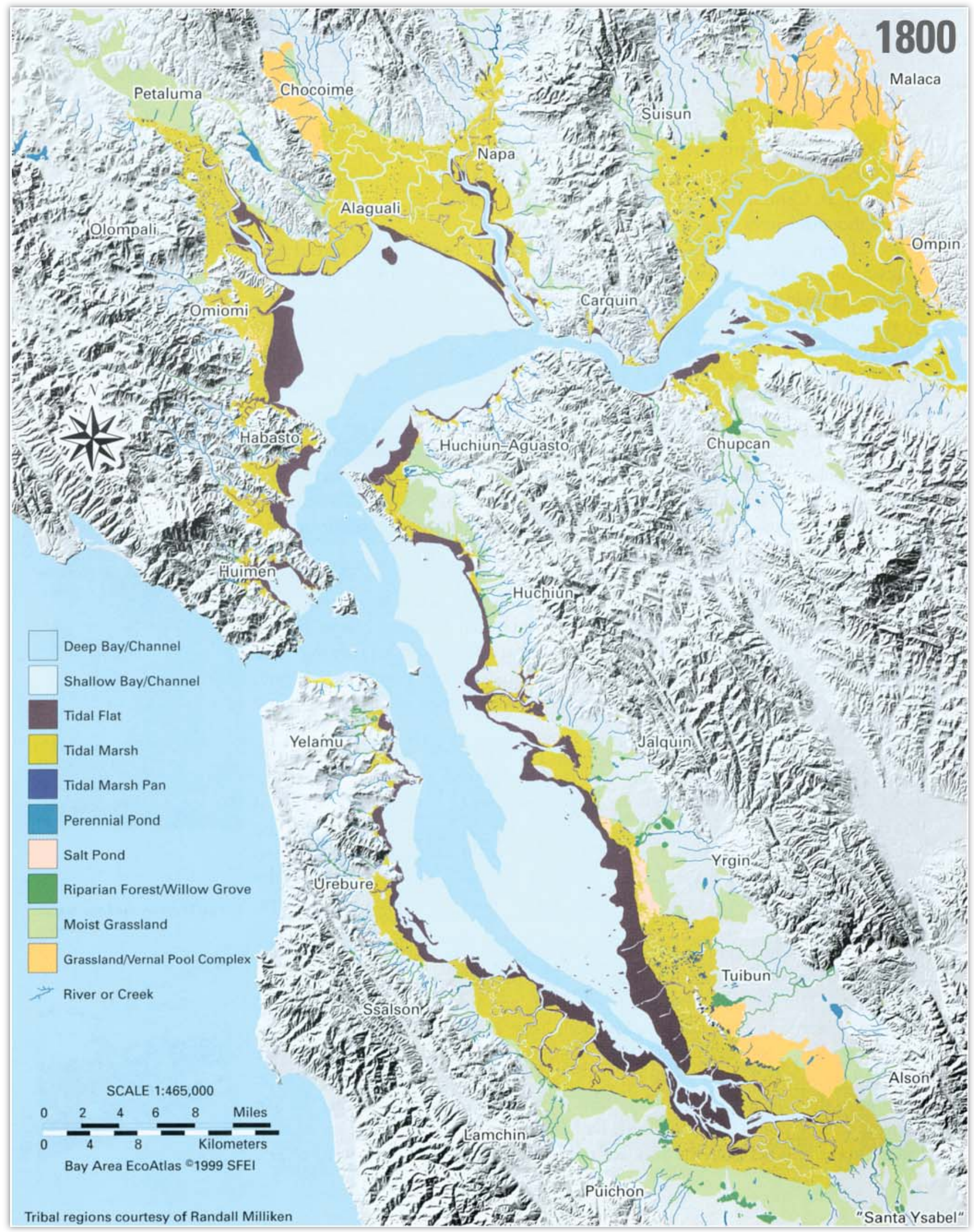

Figure 24. Vast changes have occurred to the wetlands around the San Francisco Bay and Delta estuary as a result of development and population increase. The maps show the distribution of various types of wetlands around 1800 , before any significant 


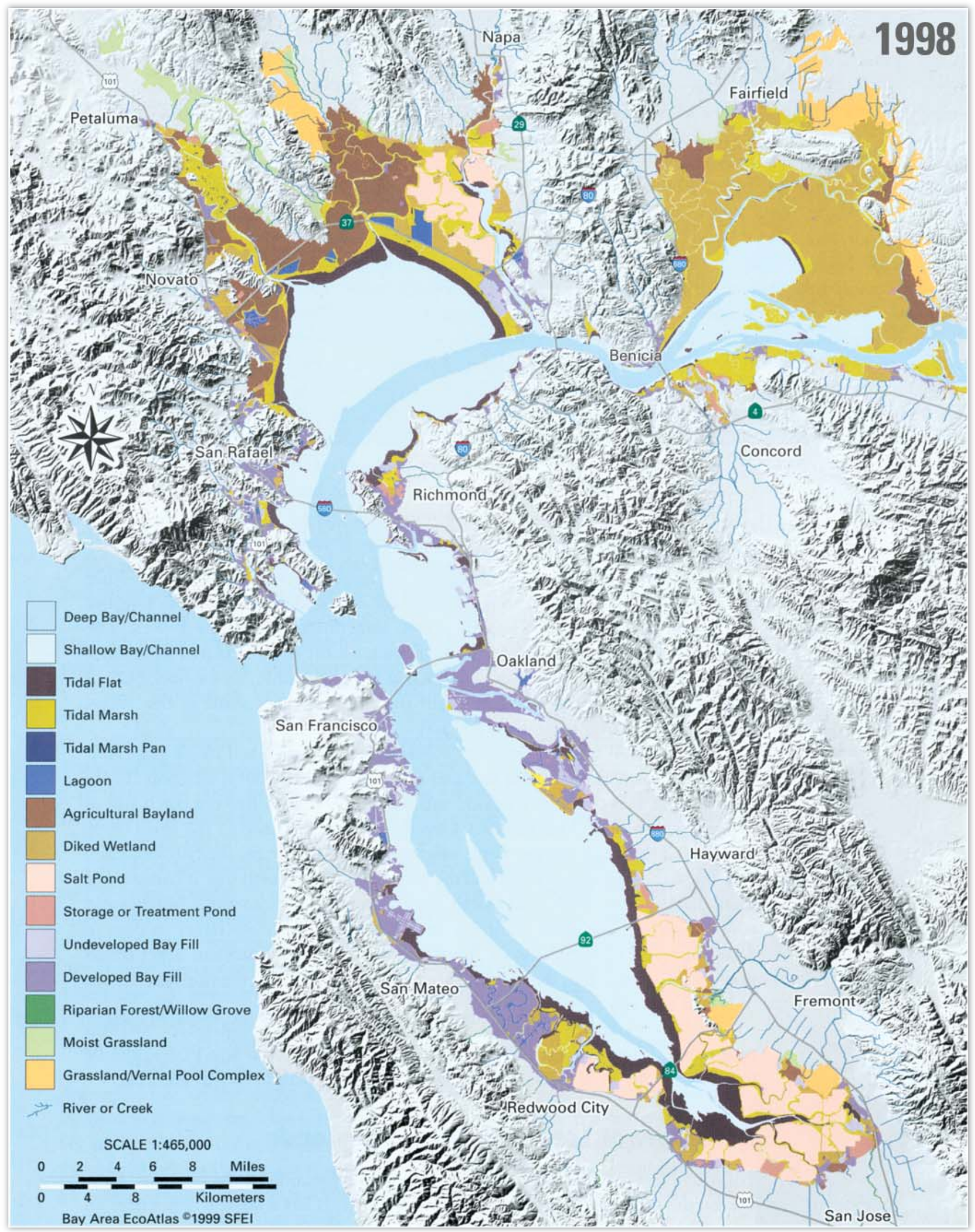

development (names on map are Native American tribal regions), and what had happened to those areas by 1998. Modified from Bay Area EcoAtlas (1999). Shaded relief by Graham and Pike (1997). 
the LTMS in San Francisco Bay appears largely dependent on the availability of local wetland restoration sites for beneficial reuse of dredged material and on the political will to continue with restoration, even at higher costs than for in-bay disposal.

Wetland restoration is at present an important process in the San Francisco Bay estuary, where more than 90 percent of the natural wetlands have been lost to man's activities since the 1800's (fig. 24). Large areas of baylands were diked off, drained, and used for agriculture. These diked areas have subsided, in many cases below the low tide elevation, and restoring them as tidal wetlands requires filling with sediment to raise them back to within the tidal range. San Francisco Bay benefits from having tidal wetland restoration sites located relatively close to ports where sediment needs to be dredged. There is an abundance of diked baylands that are well suited and politically acceptable for wetland restoration (Estuary, 1996). Many of those targeted for restoration will use dredged material beneficially. However, the cost of wetland restoration can be very great, ranging from $\$ 20,000$ to as much as $\$ 80,000$ per acre (Ernest and others, 1995).

The Port of Oakland completed its "42 ft Harbor Deepening Project” (13 m MLLW) in 1998 (Howton, 1999). A significant quantity of the dredged sediment from that major project was used at the Sonoma baylands wetland restoration site in San Pablo Bay (north San Francisco Bay). The port estimated that the cost to transport dredged material the additional distance to Sonoma baylands, rather than locally to the nearby Alcatraz Disposal Site, increased their disposal costs by less than 5 percent (Ernest and others, 1995). Disposal of dredged material at the wetland restoration site cost $\$ 10$ per cubic yard, disposal at SFDODS cost $\$ 8$ per cubic yard, and onland disposal of mildly contaminated mud at a local golf course cost \$22 per cubic yard (Estuary, 1996).

The Port of Oakland has been in the process of dredging its harbor entrance and docking facilities to a depth of 50 feet (15 m) MLLW ("50 ft Harbor Deepening Project"). The deepening of the port entrance to 50 feet $(15 \mathrm{~m})$ is predicated on the port's desire to accommodate the latest generation of deep-draft, high-capacity container vessels. These newer vessels carry more units of cargo at lower cost per unit, producing economies of scale (Port of Oakland, Vision 2000: unpub. data accessed online November 29, 2000, at http: //www.portofoakland.com/maritime/vision_02.html). The deep-draft container vessels, which draw 50 feet $(15 \mathrm{~m})$ fully loaded, are expected within several years to make up more than 75 percent of the world's container ship capacity.

The Port of Richmond recently completed deepening its harbor to 40 feet $(12 \mathrm{~m})$ MLLW. The largest oil tankers calling at the port already draw almost 40 feet of water. The Port of San Francisco has harbor facilities that are as deep as 43 feet $(13 \mathrm{~m})$ MLLW. Its facilities are mainly used for other non-cargo purposes, such as the berthing of tugboats, cruise ships, and passenger ferries (San Francisco Bay Conservation and Development Commission and Oakland Metropolitan Transportation Commission, 1996).

\section{Conclusion}

San Francisco Bay is one of the world's most beautiful natural harbors and a magnet both for maritime trade and for millions of visitors. Two hundred years ago, the natural environment of the bay had hardly been affected by the presence of local communities of Native Americans and very small numbers of Europeans. All that changed with the discovery of gold in California in the middle of the 19th century. San Francisco became the gateway for ships bearing miners, settlers, and commercial trade. The population of the bay region burgeoned, and great cities, ports, bridges, and other engineering works were built. The bay area's population and associated development have increasingly changed the estuary and its environment. The bay became a resource for dredged material to provide fill, and also a place to dispose of material excavated from waterways. Much of this activity was in the central part of the bay, where the major shipping lanes diverge after passing through the Golden Gate. To provide adequate water depth for the increasing draft of ships, emergent or shallow bedrock knobs were repeatedly blasted. By the late 20th century, San Francisco Bay had become a heavily urbanized estuary perhaps more modified by man's activities than any other major estuary in the United States.

The floor of San Francisco Bay is hidden beneath its scenic surface, and the changes man has made there since the Gold Rush are not readily visible. However, studies by the U.S. Geological Survey and others have revealed details of the transformed floor of the bay-depressions and grooves on shoals excavated by dredging, shallow areas created by irregular piles of disposed material, and shattered rocks on the truncated tops of bedrock knobs. The bay continues to be affected by human activities, interacting dynamically with the natural physical, chemical, and biological processes that constantly mold its environment, and the future surely will see more modifications. Scientific studies of these varied processes and activities and their likely consequences will help provide the understanding on which wise planning decisions can be based. Providing safe navigation channels for commercial vessels of ever-deeper drafts while also protecting the biological habitats in the bay will provide critical and complex challenges for the future.

\section{Acknowledgments}

A number of individuals contributed to this paper. We would especially like to thank Dave Cacchione, Dave Rubin, Pat Chavez, Bruce Rogers, Jim Gardner, Pete Dartnell, Hank Chezar of the USGS, the USGS Marine Facility, Capt. Thomas Richards (NOAA), Art Kleiner (C\&C Technologies), and Capt. Gordon Smith (University of California, Santa Cruz). We also thank Steve Goldbeck (BCDC) and Steve Eittreim (USGS) for their constructive reviews. 


\section{References}

Atwater, B.F., 1979, Ancient processes at the site of southern San Francisco Bay-Movement of the crust and changes in sea level, in Conomos, T.J.. ed., San Francisco BayThe urbanized estuary: San Francisco, Calif., Pacific Division, American Association for the Advancement of Science, p. 31-45.

The Bay Institute, 1998, From Sierra to the sea-The ecological history of the San Francisco Bay-Delta watershed: San Rafael, Calif., The Bay Institute of San Francisco, 248 p. [URL http://www.bay.org/sierra_to_the_sea.htm]

Bonilla, M.G., 1991, Geologic and historical factors affecting earthquake damage, in O'Rourke, T.D., ed., The Loma Prieta, California, earthquake of October 17, 1989-Marina District: U.S. Geological Survey Professional Paper 1551-F, p. 7-34.

Carlson, P.R., and McCulloch, D.S., 1970, Bedrock-surface map of central San Francisco Bay: U.S. Geological Survey-HUD Basic Data Contribution, 1 sheet, scale approx. 1:16,000.

Carlson, P.R., Alpha, T.R., and McCulloch, D.S., 1970, The floor of central San Francisco Bay: California Division of Mines and Geology, Mineral Information Service, v. 23, no. 5, p. 97-107.

Carlson, P.R., Chin, J.L., and Wong, F.L., 2000, Bedrock knobs, San Francisco Bay-Do navigation hazards outweigh other environmental problems?: Environmental and Engineering Geosciences, v. VI, no. 1, p. 41-55. [URL http: //www.geosociety.org/pubs/eeg/0002.htm]

Chameau, J.L., Clough, G.W., Reyna, F., and Frost, J.D., 1991, Liquefaction response of San Francisco bayshore fills: Seismological Society of America Bulletin, v. 81, no. 5, p. 1998-2018.

Chin, J.L., and Clifton, H.E., 1990, Surficial characteristics of the bayfloor of South San Francisco, San Pablo, and Suisun Bays, California: U.S. Geological Survey Open-File Report 90-665, 3 sheets, scale 1:50,000.

Chin, J.L., Carlson, P.R., and Wong, F.L., 1997, Multibeam data and socio-economic issues in west-central San Francisco Bay (CA) [abs. and poster]: EOS, Transactions, American Geophysical Union, v. 78, no. 46, p. F349. [URL http://sfbay.wr.usgs.gov/access/mapping/multibeam/]

Chin, J.L., Wong, F.L., and Carlson, P.R., 1998, Anthropogenic impacts on the bayfloor of west-central San Francisco Bay (CA) [abs. and poster]: EOS, Transactions, American Geophysical Union, v. 79, no. 45, p. F511-512.

Clifton, H.E., Anima, R.J., and Chin, J.L., 1991, Modern sediments of San Francisco Bay: Geological Society of America, Abstracts with Programs, v. 23, no.2, p. 14.

Conomos, T.J., 1979, Properties and circulation of San Francisco Bay waters, in Conomos, T.J., ed., San Francisco Bay_The urbanized estuary: San Francisco, Calif., Pacific Division, American Association for the Advancement of Science, p. 47-84.

Cruickshank, M.J., and Hess, H.D., 1975, Marine sand and gravel mining: Oceanus, v. 19, no. 1, p. 32-44.

Day, W.P., 1938, Exposition celebrates bridge achievements: Engineering News-Record, v.121, no.15, p. 457-467.
Dow, G.R., 1973, Bay fill in San Francisco-A history of change: California State University at San Francisco, San Francisco, Calif., M.A. thesis, 249 p.

Ernest, J., Leahy, A., and Marcus, L., 1995, What price restoration?: Estuary, San Francisco Estuary Project, San Francisco, Calif., April 1995, p.1-5. [URL http://198.31.87.76/ 1995_04/cover.php]

Estuary, 1996, A tale of three harbors: San Francisco Estuary Project, San Francisco, Calif., April 1996. [URL http: //198.31.87.76/1996_04/article_06.php]

Friends of the Estuary, 1997, Annual report, 1996-1997, 8 p. Gilbert, G.K., 1917, Hydraulic mining debris in the Sierra Nevada: U.S. Geological Survey Professional Paper 105, $154 \mathrm{p}$.

Goals Project, 1999, Baylands ecosystem habitat goals-A report of habitat recommendations prepared by the San Francisco Bay Area Wetlands Ecosystem Goals Project: U.S. Environmental Protection Agency./ San Francisco Bay Regional Water Quality Control Board, 295 p. [URL http: //www.sfei.org/sfbaygoals/]

Goldbeck, S., 1999, Mud put to good use: Oakland, Calif., California Coastal Conservancy, California Coast and Ocean, p. 17. [URL http://www.coastalconservancy.ca.gov/ coast\&ocean/winter98/a06.htm]

Graham, S.E., and Pike, R.J., 1997, Shaded-relief map of the San Francisco Bay region, California: U.S. Geological Survey Open-File Report 97-745B, 8 p.

deGroot, S.J., 1979, An assessment of the potential environmental impact of large-scale sand-dredging for the building of artificial islands in the North Sea: Ocean Management, v.5, p. 211-232.

Hagwood, J.J., 1982, Engineers at the Golden Gate: U.S. Army Corps of Engineers, 453 p.

Herbich, J.B., 2000, Deepening U.S. ports-Current challenges: Sea Technology, March 2000, p. 77.

Howton, E., 1999, Accord signed for bay dredging: San Jose Mercury News, July 17, 1999.

Karl, H.A., Chin, J.L., Ueber, Edward, Stauffer, P.H., and Hendley, J.W. II, eds., 2001, Beyond the Golden GateOceanography, geology, biology, and environmental issues in the Gulf of the Farallones: U.S. Geological Survey Circular 1198, 78 p. [printed], 235 p. [CD]. [URL http: //geopubs.wr.usgs.gov/circular/c1198/]

Kelley, J.C., 1998, San Francisco Bay-Our urbanized estuary: San Francisco Urban Institute Quarterly, San Francisco State University, v. 1, no. 4, p. 30-31.

Konigsmark, T., 1998, Geologic trips, San Francisco and the Bay Area: Gualala, Calif., GeoPress, 174 p.

Long Term Management Strategy for Dredged Material Disposal, 1995, LTMS status report, July 1995 [final October 1996]: 20 p.

Markwart, A.H., 1915, Engineering problems of the PanamaPacific Exposition: Engineering News-Record, v. 73, no. 7, p. 329-336.

Nichols, D.R., and Wright, N.A., 1971, Preliminary map of historic margins of marshland, San Francisco Bay, Califor- 
nia: U.S. Geological Survey Open-File Report 71-0216, 1 sheet, 1:125,000.

Nichols, F.H., 1979, Natural and anthropogenic influences on benthic community structure in San Francisco Bay, in Conomos, T.J., ed., San Francisco Bay-The urbanized estuary: San Francisco, Calif., Pacific Division, American Association for the Advancement of Science, p. 409-426.

Nichols, F.H., Cloern, J.E., Luoma, S.N., and Peterson, D.H., 1986, The modification of an estuary: Science, v. 231, p. 567-573.

Nolte, C., 1997, Underwater rocks hazardous to Bay: San Francisco Chronicle, February 21, 1997.

Pacific Coast Federation of Fisherman's Associations, 1997, Fishermen call for navigation improvements in San Francisco Bay: News Release no. 97-3, 3 p.

Patella, L.M., 2000, Dredging creates a strong economy and cleaner environment: Sea Technology, May 2000, p. 81.

Pisani, J.M., 1989, Port development in the U.S.-Status and outlook: Oceanus, v. 32, no. 3, p. 36-45.

Rogers, P., 1996, Plan to avert bay oil spill gains steam: San Jose Mercury News, March 16, 1996.
Rubin, D.M., and McCulloch, D.S., 1979, The movement and equilibrium of bedforms in Central San Francisco Bay: in Conomos, T.J., ed., San Francisco Bay-The urbanized estuary: San Francisco, Calif., Pacific Division, American Association for the Advancement of Science, p. 97-113.

San Francisco Bay Conservation and Development Commission, and Oakland Metropolitan Transportation Commission, 1996, San Francisco Bay Area Seaport Plan: 62 p.

Scheffauer, F.C., 1954, The hopper dredge, its history, development, and operation: U.S. Army Corps of Engineers, 399 p.

U.S. Army Corps of Engineers, 2003, San Francisco Central Bay rock removal project; feasibility study reference report: U.S. Army Corps of Engineers, San Francisco District, and California State Lands Commission, 58 p. [URL http: //www.spn.usace.army.mil/]

U.S. Environmental Protection Agency, 1996, Long-term management strategy (LTMS) for the placement of dredged material in the San Francisco Bay Region, Draft, April 1996 [final October 1996]: vol. 1, 500 p. [URL http: //www.spn.usace.army.mil/ltms/] 